\title{
Invited review: Physiological properties of bioactive peptides obtained from whey proteins
}

\author{
A. R. Madureira, T. Tavares, A. M. P. Gomes, M. E. Pintado, and F. X. Malcata ${ }^{1}$ \\ Centro de Biotecnologia e Quımica Fina (CBQF)/Escola Superior de Biotecnologia, Universidade Católica Portuguesa, \\ R. Dr. António Bernardino de Almeida, P-4200-072 Porto, Portugal
}

\begin{abstract}
Processing of whey proteins yields several bioactive peptides that can trigger physiological effects in the human body: on the nervous system via their opiate and ileum-contracting activities; on the cardiovascular system via their antithrombotic and antihypertensive activities; on the immune system via their antimicrobial and antiviral activities; and on the nutrition system via their digestibility and hypocholesterolemic effects. The specific physiological effects, as well the mechanisms by which they are achieved and the stabilities of the peptides obtained from various whey fractions during their gastrointestinal route, are specifically discussed in this review.
\end{abstract}

Key words: whey, bovine, peptide, bioactivity

\section{INTRODUCTION}

Whey proteins account for only about $20 \%$ (wt/wt) of the whole milk protein inventory, whereas caseins account for the most part. Whey proteins are globular molecules with substantial contents of $\alpha$-helix motifs, in which acidic/basic and hydrophobic/hydrophilic AA are balanced throughout their sequences. The whey proteins include $\beta$-LG, $\alpha-\mathrm{LA}$, immunoglobulins, BSA, bovine lactoferrin (BLF), and lactoperoxidase, in addition to other minor proteinaceous components, such as glycomacropeptide (GMP), which is released from $\kappa$-casein in the first step of enzymatic cheesemaking. These proteins possess important nutritional and biological properties, particularly with regard to promotion of health and prevention of diseases and health conditions (Madureira et al., 2007).

Controlled hydrolysis of whey proteins releases bioactive peptides, most of which have not yet been characterized to the same degree as casein-derived peptides; see, for example, the comprehensive review by Silva and Malcata (2004) on this subject. However, whey peptides have the potential to play important roles in

Received July 14, 2009.

Accepted September 18, 2009.

${ }^{1}$ Corresponding author: fxmalcata@esb.ucp.pt several areas of interest; namely as part of preventive and therapeutic health approaches, because of a favorable combination of various biochemical and physiological features (Meisel, 1998). Experimental evidence exists that bioactive peptides can be released from $\alpha$-LA, $\beta-\mathrm{LG}, \mathrm{BLF}$, and BSA; some of these bioactive peptides have received special designations: $\alpha$ - and $\beta$-lactorphin, $\beta$-lactotensin, serophin, albutensin A, lactoferricin B, and lactoferrampin (although many others exist).

Besides being susceptible to inorganic (acid or alkaline) catalysis, whey proteins can be hydrolyzed via gastric, pancreatic, and microbial proteases, and thus generate peptides that may play physiological roles (Figure 1). These roles have been addressed by several researchers (Shah, 2000; Smacchi and Gobbetti, 2000; Baró et al., 2001; Meisel and FitzGerald, 2003; Korhonen and Pihlanto, 2003) but with an emphasis on nutritional features. The physiological roles will be further discussed in this paper under a more global, yet integrated perspective. This review thus adds to other published work on the topic of whey protein characteristics and uses, and on the physiological roles of dairy peptides. However, it focuses specifically on biopeptides obtained from whey.

\section{PRODUCTION OF BIOACTIVE PEPTIDES}

There are various modes of release of peptides (with biological activity) from precursor proteins or synthesis thereof from simpler molecules; the most frequent are described in Figure 2 and considered in detail below.

Starter and nonstarter bacteria are commonly used in the manufacture of dairy products and they take advantage of their proteolytic system, which contains at least 16 different peptidases. However, few bioactive peptides starting from whey proteins as precursors are typically obtained. This fact can be explained in several ways: more studies have been published pertaining to milk than whey, as more numerous dairy products are manufactured with whole milk than with whey, and some of them are released via rennet or other coagulants; and caseins are in higher proportion than whey proteins in milk, so they are more readily available for catalysis, although controversial discussions have been 


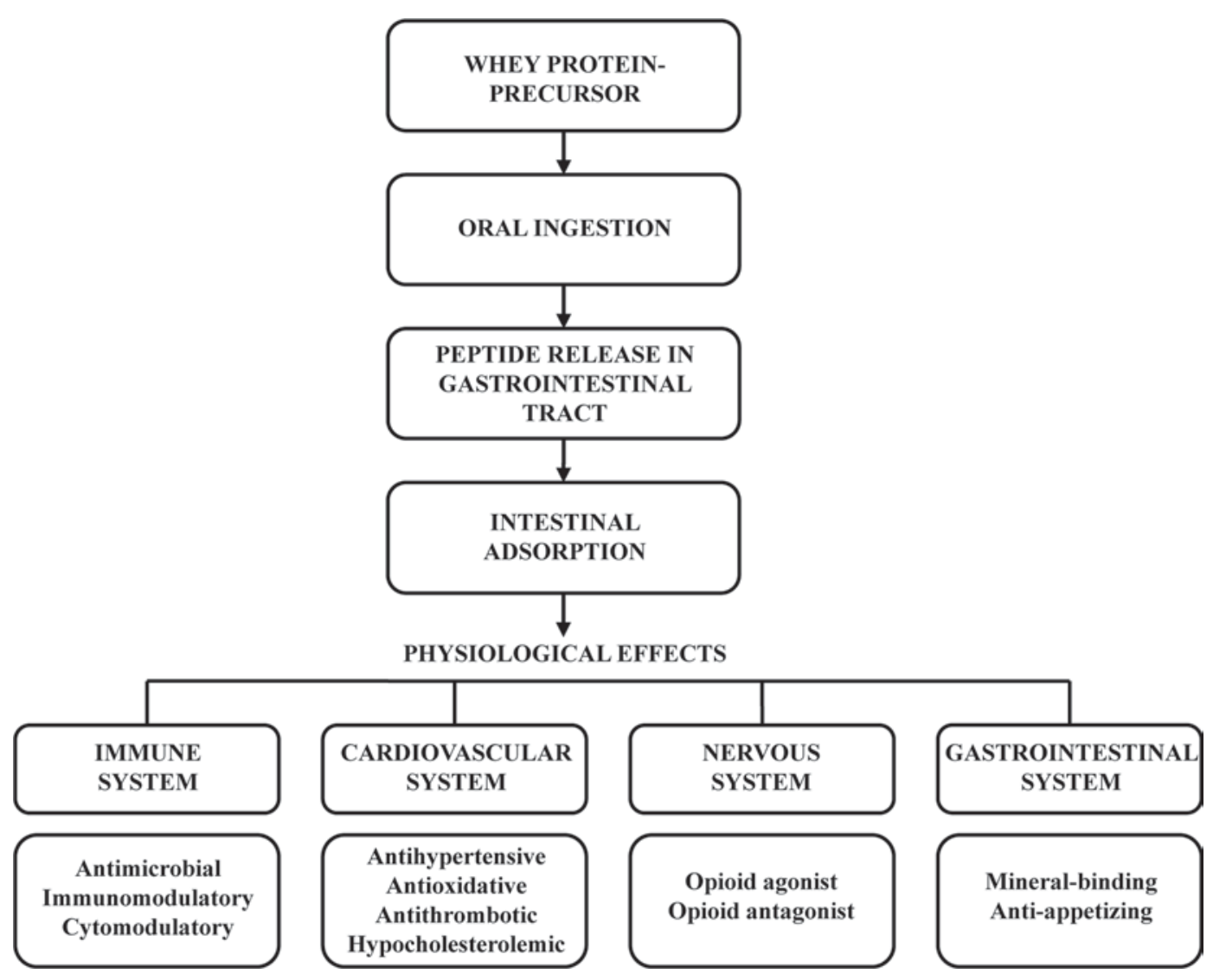

Figure 1. Physiological framework of bioactivity of whey peptides.

carried out on the resistance of whey proteins to breakdown by bacterial peptidases.

The major whey proteins, $\alpha-\mathrm{LA}$ and $\beta-\mathrm{LG}$, are resistant to the endogenous enzymes present in milk, such as plasmin. Plasmin (EC 3.4.21.7) is a serine proteinase, similar to trypsin in its activity and characteristics; it hydrolyzes $\alpha_{\mathrm{S1}^{-}}, \alpha_{\mathrm{S}^{-}}$and $\beta$-caseins, but has little or no activity on whey proteins (Grufferty and Fox, 1988; Cassens et al., 1999). Plasmin cleaves proteins on the carboxyl side of $\mathrm{K}$ and $\mathrm{R}$ residues (Kitchen, 1985), with a preference for the former. Furthermore, unfolded $\beta$-LG can be a potent inhibitor of plasmin via thiol-disulfide binding (Scollard et al., 2000).

Despite the relative difficulty in obtaining peptides by microbial hydrolysis, enzymatic hydrolysis has been the most common route to produce bioactive peptides from whey proteins, and pancreatic enzymes (chiefly trypsin) have been associated with efforts toward production, as well as characterization and identification of many peptides (see Table 1). Trypsin cleaves at the $\mathrm{C}$-terminal end of $\mathrm{R}$ and $\mathrm{K}$ residues, whereas chymotrypsin requires an aromatic or bulky nonpolar side chain (e.g., F, Y, W, L, or M) on the carboxyl side of the bond subject to cleavage.
In practice, enzymatic hydrolysis can be performed in 1 of 2 ways: in a batch or continuous manner (ultrafiltration for enzyme containment is often used in this case). Hydrolysis of whey proteins brought about by Alcalase (Novo Industry AS, Copenhagen, Denmark) using a membrane recycle reactor has been described (Perea and Ugalde, 1996), as has production of $\alpha$-lactorphin via continuous hydrolysis of goat whey in an ultrafiltration reactor (Bordenave et al., 1999). Opioid peptides, such as $\alpha$ - and $\beta$-lactorphin, can also be obtained via selective ultrafiltration membranes $(30$ and $1 \mathrm{kDa}$ cutoffs, respectively); this method was claimed (Korhonen and Pihlanto, 2003) to produce final peptide mixtures with high angiotensin-I-converting enzyme (ACE)inhibitory activity, owing to a selective concentration of low-molecular-weight peptides.

Alternatively, one may resort to peptide synthesis, and the main typical approaches here are depicted in Figure 2; the most suitable method for synthesis depends mainly on the length and amount of the peptides sought. Chemical synthesis, starting from free AA, is normally used on the laboratory scale. Chemical synthesis exists in 2 variants, the liquid and the solid phase; the former is used for generation of short pep- 


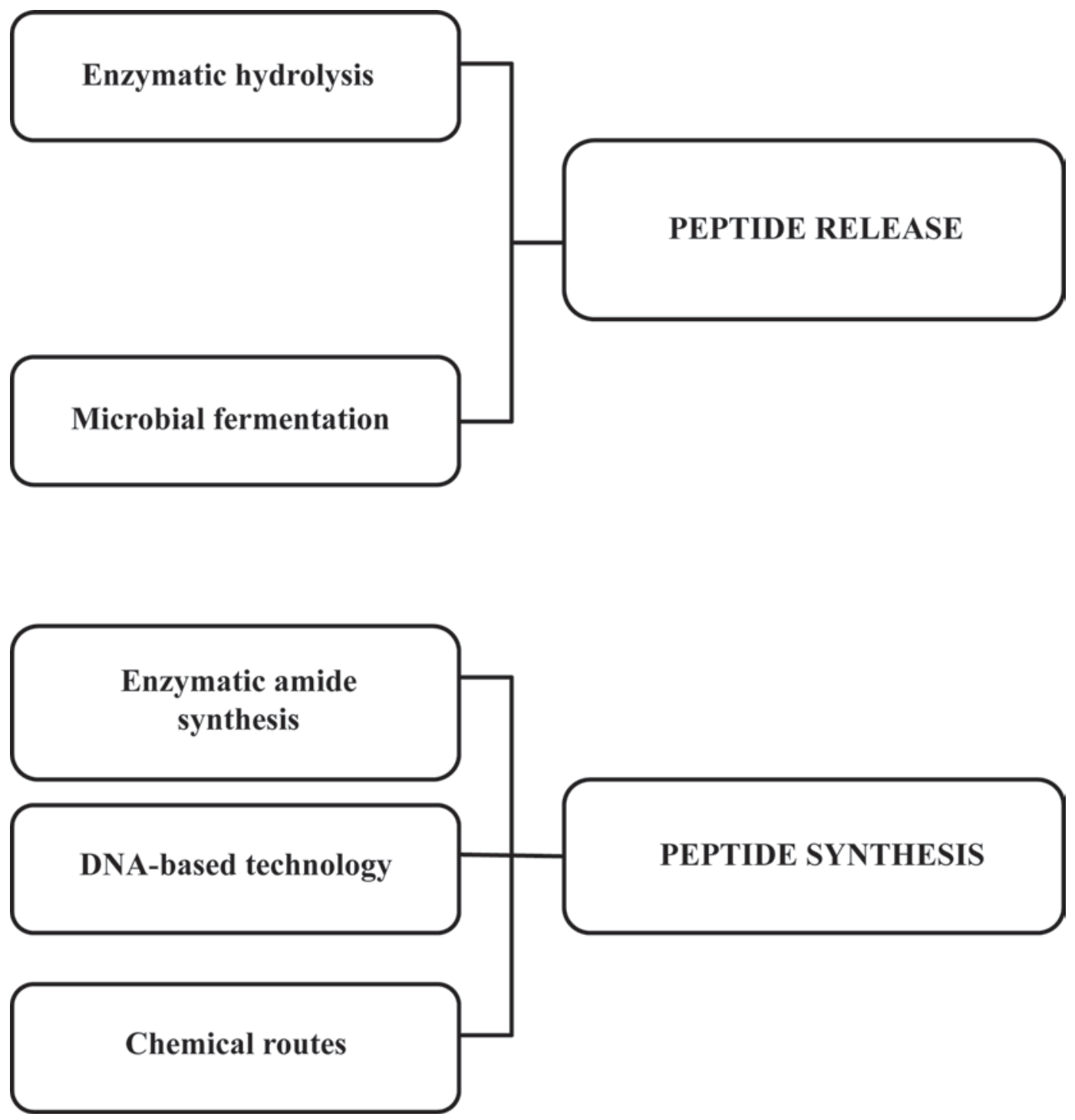

Figure 2. Alternative modes of bioactive peptide generation. Peptide release and synthesis pathways.

tides, whereas the latter is more common for synthesis of peptides composed of 10 to 100 residues. Conversely, enzymatic synthesis is performed for shorter sequences, whereas DNA recombinant technology applies mainly to large peptides (Iqbal et al., 1996).

\section{PEPTIDES WITH ANTIHYPERTENSIVE AND ANTITHROMBOTIC ACTIVITIES}

One of the major risk factors for cardiovascular disease is elevated blood pressure. Angiotensin I-converting enzyme plays a crucial role in the regulation of blood pressure, because it promotes the conversion of angiotensin I to the potent vasoconstrictor angiotensin II and inactivates the vasodilator bradykinin (Figure 3). By inhibiting these processes, synthetic ACE inhibitors have long been used as antihypertensive agents. Milk proteins were identified as sources of ACE inhibitory peptides and are currently the best-known class of bioactive peptides.

\section{Peptides from $\alpha-L A$ and $\beta-L G$}

The ACE-inhibiting peptides derived from casein are termed casokinins, whereas those derived from whey $(\alpha-\mathrm{LA}$ and $\beta-\mathrm{LG})$ are called lactokinins (FitzGerald and Meisel, 1999). Characterization of hydrolysates of whey proteins, including the amino acid sequences of peptides therein that exhibit in vitro ACE-inhibiting activity or in vivo antihypertensive effects, is provided in Table 2. Inhibition of ACE is classically measured as the concentration of compound needed to inhibit $50 \%$ 
Table 1. Peptides obtained from the main whey proteins, enzymes used to obtain those peptides, and resulting amino acid sequence and biological activity

\begin{tabular}{|c|c|c|c|c|c|c|}
\hline $\begin{array}{l}\text { Source } \\
\text { protein }\end{array}$ & Enzyme & Peptide & Amino acid sequence & Identity & Bioactivity $^{1}$ & References \\
\hline \multirow[t]{4}{*}{$\alpha-L A$} & \multirow[t]{2}{*}{ Trypsin } & \multirow[t]{2}{*}{-} & $\mathrm{f}(1-5)$ & EQLTK & \multirow[t]{3}{*}{$\begin{array}{l}\text { Antimicrobial against several } \\
\text { gram-positive bacteria }\end{array}$} & \multirow[t]{3}{*}{ Pellegrini et al. (1999) } \\
\hline & & & $\mathrm{f}(17-31) \mathrm{S}-\mathrm{Sf}(109-114)$ & GYGGVSLPEWVCTTF & & \\
\hline & \multicolumn{2}{|l|}{ Chymotrypsin } & $\mathrm{f}(61-68) \mathrm{S}-\operatorname{Sf}(75-80)$ & CKDDQNPH: $\alpha$-chain & & \\
\hline & Pepsin & $\alpha$-Lactorphin & $\mathrm{f}(50-53)$ & YGLF & $\begin{array}{l}\text { Opioid agonist; ACE-inhibitory; } \\
\text { ileum contracting }\end{array}$ & $\begin{array}{l}\text { Antila et al. (1991) } \\
\text { Mullally et al. (1996) } \\
\text { Meisel and Schlimme (1996) } \\
\text { Nurminen et al. (2000) }\end{array}$ \\
\hline \multirow[t]{6}{*}{$\beta-L G$} & \multirow[t]{3}{*}{ Trypsin } & \multirow[t]{3}{*}{-} & $f(15-20)$ & VAGTWY & \multirow{3}{*}{$\begin{array}{l}\text { ACE-inhibitory; antimicrobial } \\
\text { against several } \\
\text { gram-positive bacteria } \\
\text { Antimicrobial against several } \\
\text { gram-positive bacteria }\end{array}$} & $\begin{array}{l}\text { Ijäs et al. (2004) } \\
\text { Pellegrini et al. (1999) }\end{array}$ \\
\hline & & & $f(25-40)$ & AASDISLLDAQSAPLR & & Pellegrini et al. (2000) \\
\hline & & & $\begin{array}{l}\mathrm{f}(78-83) \\
\mathrm{f}(92-100)\end{array}$ & $\begin{array}{l}\text { IPAVFK } \\
\text { VLVLDTDYK }\end{array}$ & & \\
\hline & Pepsin; trypsin & $\beta$-Lactorphin & $\mathrm{f}(102-105)$ & YLLF & $\begin{array}{l}\text { Opioid agonist; ACE-inhibitory; } \\
\text { ileum-contracting }\end{array}$ & $\begin{array}{l}\text { Antila et al. (1991) } \\
\text { Mullally et al. (1996) } \\
\text { Meisel and Schlimme (1996) } \\
\text { Sipola et al. (2002) }\end{array}$ \\
\hline & Porcine trypsin & - & $\mathrm{f}(71-75)$ & IIAEK & Hypocholesterolemic & Nagaoka et al. (2001) \\
\hline & Chymotrypsin & $\beta$-Lactotensin & $f(146-149)$ & HIRL & $\begin{array}{l}\text { ACE-inhibitory; ileum } \\
\text { contracting; antinoceptive } \\
\text { activity; hypertensive activity }\end{array}$ & $\begin{array}{l}\text { Pihlanto-Leppälä et al. (1997) } \\
\text { Yamauchi et al. (2003b) }\end{array}$ \\
\hline \multirow{2}{*}{$\begin{array}{l}\text { Serum } \\
\text { albumin }\end{array}$} & \multirow[t]{2}{*}{ Trypsin } & \multirow{2}{*}{$\begin{array}{l}\text { Albutensin A } \\
\text { Serophin }\end{array}$} & \multirow{2}{*}{$\begin{array}{l}f(208-216) \\
f(399-404)\end{array}$} & \multirow{2}{*}{$\begin{array}{l}\text { AFKAWAVAR } \\
\text { YGFGNA }\end{array}$} & \multirow{2}{*}{$\begin{array}{l}\text { Ileum contracting } \\
\text { Opioid activity }\end{array}$} & Yamauchi (1992) \\
\hline & & & & & & $\begin{array}{l}\text { Tani et al. (1993) } \\
\text { Meisel and Schlimme (1996) }\end{array}$ \\
\hline
\end{tabular}

${ }^{1} \mathrm{ACE}=$ angiotensin-I-converting enzyme. 


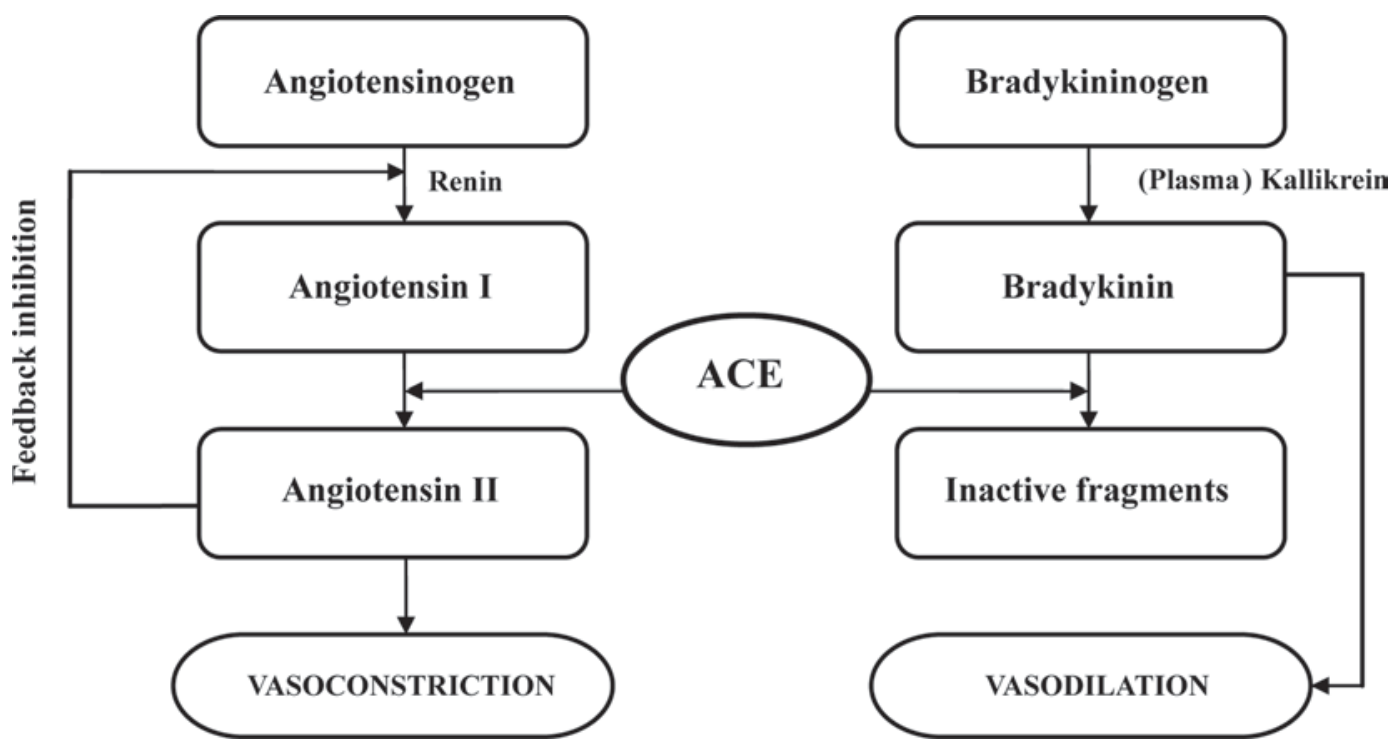

Figure 3. Schematic representation of the renin-angiotensin system, demonstrating the balance between angiotensin and bradykinin. Angiotensin-I-converting enzyme (ACE) plays a central role in converting angiotensin I to angiotensin II and in deactivating bradykinin.

of the original ACE activity ( $\mathbf{I C}_{50}$; Gerdes et al., 2002). The heptapeptide ALPMHIR from $\beta$-LG is the most potent ACE-inhibitor $\left(\mathrm{IC}_{50}=43 \mu M\right)$ isolated from whey to date. As shown in Table 2, trypsin has been the most widely used enzyme to produce hydrolysates with reasonable ACE-inhibiting activity.

At present, the main challenge in the production of bioactive peptides by enzymatic hydrolysis in vitro is finding the suitable enzyme and hydrolysis conditions that enhance bioactivity and yield in their production. Digestion of $\alpha$-LA and $\beta-L G$ by enzymes (e.g., pepsin, $\alpha$-chymotrypsin, pancreatin, elastase, or carboxypeptidase A and B) indicates that trypsin is normally required to produce high ACE-inhibitory activity from these whey proteins (Pihlanto-Leppälä et al., 2000); for example, the peptides $\mathrm{f}(104-108)$ and $\mathrm{f}(142-148)$, released from $\alpha$-LA and $\beta-L G$ via trypsin, possess ACEinhibiting activities of 77 and $43 \mu M$, respectively. On the other hand, the gastrointestinal protease elastase is associated with a poor yield of ACE-inhibitory peptides from $\alpha$-LA and $\beta$-LG (Mullally et al., 1997; Pihlanto-Leppälä et al., 2000). A new food-grade proteolytic preparation was tested for the production of novel $\beta$-LG-derived ACE inhibitory peptides (OrtizChao et al., 2009). Protease N Amano (EC 3.4.24.28) is a commercial proteolytic mixture produced by Bacillus subtilis fermentation, which was found to produce very complex peptide mixtures; the partially fractionated hydrolysates already had very potent ACE inhibitory activity. The novel heptapeptide SAPLRVY was isolated and characterized. It corresponded to $\beta$-LG f(36-42) and had an $\mathrm{IC}_{50}$ value of $8 \mu M$, which is considerably lower than that of the most potent ACE inhibitory peptides derived from bovine $\beta-\mathrm{LG}$.

The importance of hydrophobic amino acid residues in the peptide sequence toward ACE inhibition has been discussed at some length (Cheung et al., 1980): such aromatic amino (W, Y, and F) or imino (P) C-terminal residues contribute to expression of ACE-inhibitory activity; those C-terminal residues can indeed interact with many subsites of ACE (Ondetti and Cushman, 1982), whereas a positive charge, such as that in the guanidine group of $\mathrm{R}$, is important for ACE inhibition (Meisel, 1998): ALPM is composed of hydrophobic amino acids, and HIR has a hydrophobic (I) amino acid. It seems that the dipeptide YG is the major component responsible for such an activity in $\alpha$-lactorphin, whereas the same holds for lactoferrin regarding $\beta$-lactorphin. As shown in Figure 4, breakdown of peptides may either strengthen their ACE-inhibiting capacity (e.g., VGINYWLAHK $\rightarrow$ WLAHK, YLLF $\rightarrow$ $\mathrm{YL}$, and HIRL $\rightarrow$ IR) or weaken it (e.g., ALPMHIR $\rightarrow$ $\mathrm{ALPMH} \rightarrow \mathrm{ALPM}, \mathrm{YLLF} \rightarrow \mathrm{LF}$, and $\mathrm{HIRL} \rightarrow \mathrm{RL})$; however, no apparent general trend emerges from this observation.

It should be emphasized that a high ACE-inhibiting activity in vitro does not necessarily imply a high antihypertensive activity in vivo; unfortunately, only a few in vivo studies encompassing whey protein hydrolysates are available to date (e.g., Nakamura et al., 1995; Abubakar et al., 1998; Yamamoto et al., 1999), which accordingly provide only limited validation of that statement. In particular, the peptides $\mathrm{f}(50-53)$ ( $\alpha$-lactorphin) (Nurminen et al., 2000) and $\mathrm{f}(78-80)$ 
Table 2. Angiotensin I-converting enzyme (ACE)-inhibiting peptides obtained from the main whey proteins, as well as enzymes used to obtain them, resulting amino acid sequence and in vitro ACE inhibition

\begin{tabular}{|c|c|c|c|c|c|}
\hline Source protein & Enzyme & AA sequence & Identity & $\begin{array}{l}\text { In vitro } \mathrm{ACE} \\
\text { inhibition }^{1}\end{array}$ & Reference \\
\hline \multirow[t]{5}{*}{$\alpha-\mathrm{LA}$} & Trypsin & $\mathrm{f}(50-51)$ & YG & 1,522 & Mullally et al. (1996) \\
\hline & Pepsin + trypsin + chymotrypsin & $\mathrm{f}(50-52)$ & YGL & 409 & Pilhanto-Leppälä et al. (2000) \\
\hline & Pepsin & $\mathrm{f}(50-53)$ & YGLF & $733^{2}$ & Mullally et al. (1996) \\
\hline & Trypsin & $\mathrm{f}(99-108)$ & VGINYWLAHK & 327 & Pilhanto-Leppälä et al. (2000) \\
\hline & & $f(104-108)$ & WLAHK & 77 & \\
\hline \multirow[t]{10}{*}{$\beta-\mathrm{LG}$} & Trypsin & $f(22-25)$ & LAMA & 1,062 & Pilhanto-Leppälä et al. (2000) \\
\hline & & $\mathrm{f}(32-40)$ & LDAQASPLR & 635 & \\
\hline & & $f(81-83)$ & VKF & 1,029 & Mullally et al. (1997) \\
\hline & & $f(142-148)$ & ALPMHIR & 43 & \\
\hline & Synthetic & $\mathrm{f}(102-103)$ & $\mathrm{YL}$ & 122 & Mullally et al. (1996) \\
\hline & & $\mathrm{f}(104-105)$ & LF & 349 & \\
\hline & Pepsin + trypsin + chymotrypsin & $\mathrm{f}(94-100)$ & VLDTDYK & 946 & Pilhanto-Leppälä et al. (2000) \\
\hline & & $\mathrm{f}(102-105)$ & YLLF & 172 & Chiba and Yoshikawa (1991) \\
\hline & & $f(106-111)$ & CMENSA & 788 & Pilhanto-Leppälä et al. (2000) \\
\hline & & $\mathrm{f}(142-146)$ & ALPMH & 521 & \\
\hline \multirow[t]{5}{*}{ Whey } & Fermentation + trypsin + chymotrypsin & $\alpha-L A$ f $(105-110)$ & LAHKAL & 621 & Pilhanto-Leppälä et al. (1998) \\
\hline & & $\beta$-LA f $(9-14)$ & GLDIQK & 580 & Pilhanto-Leppälä et al. (1998) \\
\hline & & $\beta-\mathrm{LA} \mathrm{f}(15-20)$ & VAGTWY & 1,682 & Pilhanto-Leppälä et al. (1998) \\
\hline & Proteinase K & $f(78-80)$ & IPA & 141 & Abubakar et al. (1998) \\
\hline & Fermentation by cheese microflora & $\alpha-L A ~ f(104-108)$ & WLAHK & 77 & Didelot et al. (2006) \\
\hline
\end{tabular}

${ }^{1}$ Given as inhibitory concentration $(\mathrm{mg} / \mathrm{mL})$ that produces $50 \%$ of maximum effect $\left(\mathrm{IC}_{50}\right)$

${ }^{2}$ Blood pressure reduction effect. 

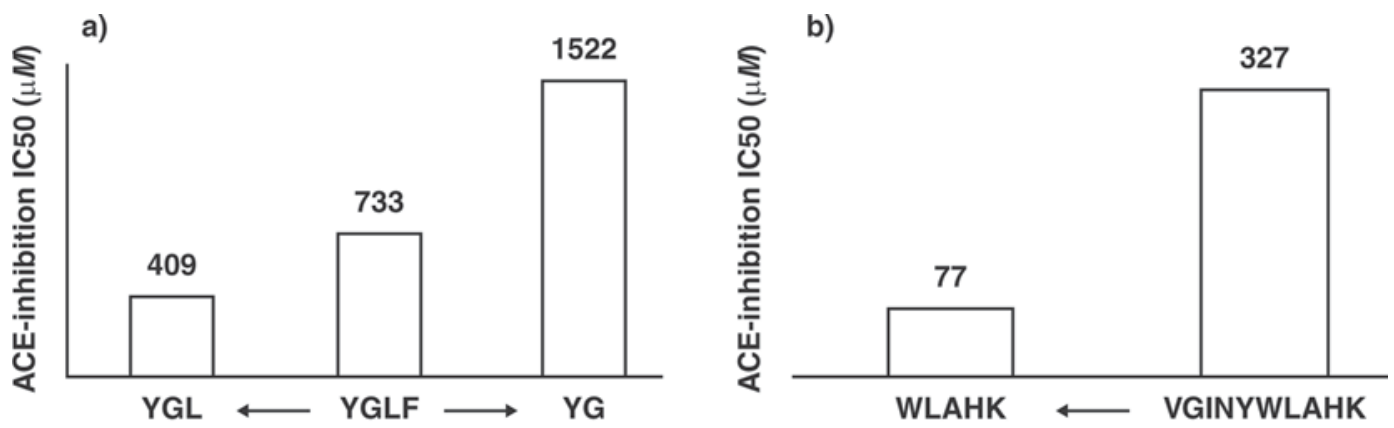

c)

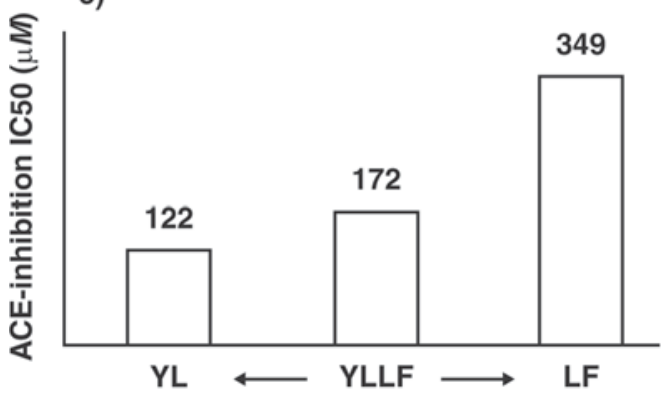

e)

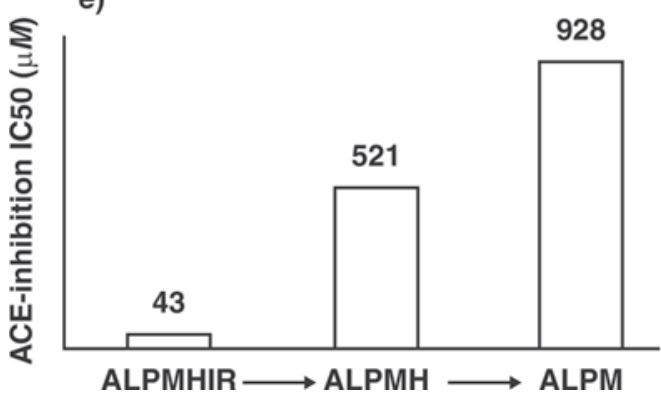

d)

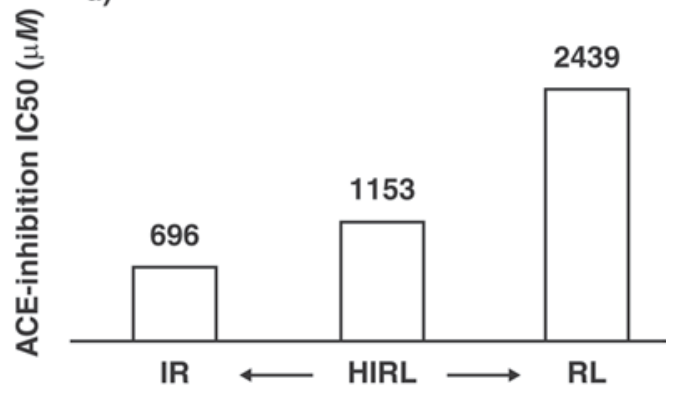

Figure 4. Evolution in degree of angiotensin-I-converting enzyme (ACE) inhibition, upon breakdown of selected whey peptides.

(lactosin A) from $\alpha$-LA (Abubakar et al., 1998), as well as $\mathrm{f}(142-145$ ) (lactosin B) from $\beta$-LG (Murakami et al., 2004) were shown to reduce blood pressure in vivo. Existence of a (negative) correlation between in vitro ACE inhibition and in vivo blood pressure decrease has been illustrated (Yamamoto et al., 1999): hydrolysates brought about by trypsin and actinase (a fungal proteinase from Actinomyces spp.) possess a relatively high in vitro ACE-inhibiting activity $(141 \mu M)$, but yield a relatively large blood pressure decrease in spontaneously hypertensive rats, whereas chemically synthesized lactosin $\mathrm{B}(\mathrm{APLM})$ showed a high $\mathrm{IC}_{50}$ value $(928 \mu \mathrm{M})$, thus indicating a weak ACE-inhibitory activity (Walsh et al., 2004).

In addition to inhibition of ACE, the exact molecular mechanisms by which the active peptides act to exert their antihypertensive effect are not fully explained, which demands future research in this area. Some of the mechanisms proposed are described in Table 3 and all proceed through increase of vascular relaxation.

At present, fragments of $\beta$-LG resulting from hydrolysis of whey protein isolate are marketed as BioZate (Danisco Foods International, Le Sueur, MN), which is claimed to reduce blood pressure. A placebo-controlled study has been conducted with the BioZate 1 product in 30 borderline hypertensive subjects for $6 \mathrm{wk}$, in which the placebo was unhydrolyzed whey protein isolate. A reduction in blood pressure of $8 \mathrm{mmHg}$ was obtained compared with the placebo group (Pins and Keenan, 2006).

\section{PEPTIDES WITH OPIOID AND ILEUM-CONTRACTING ACTIVITIES}

Whey proteins can release opioid peptides, which are atypical because of their structure $\left(\mathrm{Y}-\mathrm{X}_{1}-\mathrm{X}_{2}-\mathrm{F}\right.$, where 
$\mathrm{X}_{1}$ and $\mathrm{X}_{2}$ denote generic residues) that enables binding to cell receptors and makes them responsible for specific physiological effects (Figure 5). $\alpha$-Lactorphin, $\beta$-lactorphin, and $\beta$-lactotensin are opioid peptides (Antila et al., 1991; Pihlanto-Leppälä et al., 1997) that also have antihypertensive functions. The proposed mechanism by which the opioid effect is achieved by such peptides is depicted in Table 3. Receptors involved include neurotensin receptor (NT) 1, which is a bioactive 13AA neuropeptide that acts in the bovine hypothalamus and is involved in hypotension, food intake suppression, and analgesia, in addition to ileum contraction (TylerMcMahon et al., 2000); $\mathrm{NT}_{2}$; and dopamine antagonist $1\left(D_{1}\right)$ (Yamauchi et al., 2003b). $\alpha$-Lactorphin was found to lower blood pressure via interaction with opioid receptors, but not via ACE inhibition. In fact, subcutaneous administration of the synthetic form of $\alpha$-lactorphin in conscious, spontaneously hypertensive rats and in normotensive Wistar Kyoto rats led to lower blood pressures without affecting their heart rate (monitored by continuous radiotelemetry).

The opioid peptide produced from $\beta$-LG is $\beta$-lactotensin, which induces contraction in guinea pig ileum longitudinal muscle without electric stimulation in the absence of agonist up to a concentration of $10^{-6}$ $M$ (Yamauchi, 1992). This researcher discovered, in addition, that the smooth muscle-contracting effect of $\beta$-lactotensin is not mediated by an opioid-like mechanism. Furthermore, albutensin A, which is derived from BSA via tryptic digestion, exhibits an ileum-contracting activity (Tani et al., 1993).

\section{PEPTIDES WITH ANTIMICROBIAL AND IMMUNOMODULATORY ACTIVITIES}

\section{Peptides from $\alpha-L A$ and $\beta-L G$}

Peptides were produced (Pellegrini et al., 1999, 2000) via proteolytic digestion of $\alpha-L A$ and $\beta-L G$ by endopeptidases and were found to possess bactericidal properties, mainly against gram-positive bacteria (see Table 4).

Trypsin-mediated hydrolyses of bovine $\alpha$-LA yielded interesting polypeptide fragments, which are depicted in Table 1 ; similar digestion of $\beta$-LG yielded 4 peptide fragments, all of which possess bactericidal activity. When synthesized in vitro, those 4 peptides were thought (Pellegrini et al., 1999) to exert bactericidal effects against gram-positive bacteria only, and Bacillus subtilis was the most susceptible among the species tested. In the case of peptide $\mathrm{f}(92-100)$, its amino acid sequence was then deliberately modified to ascertain the structural requirements for antibacterial activity. Replacement of D98 by $\mathrm{R}$, and addition of $\mathrm{K}$ at the

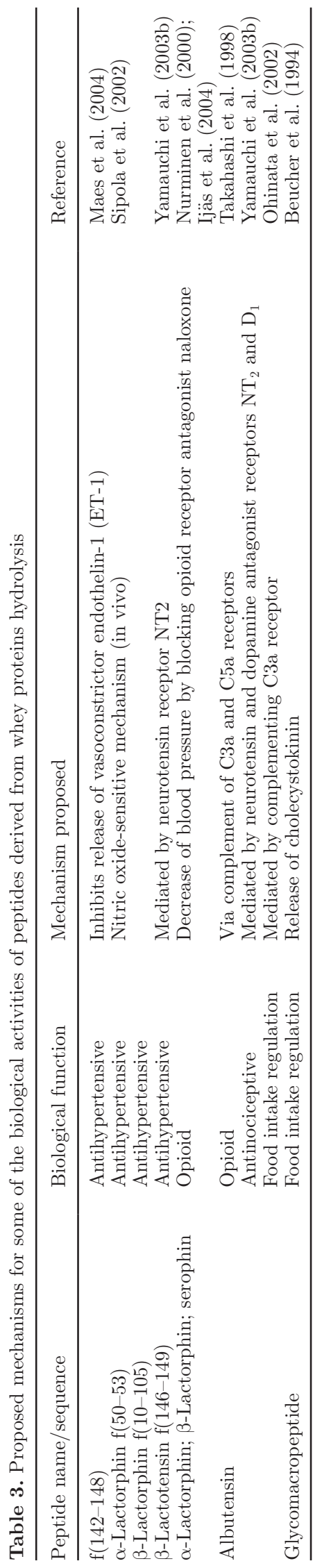



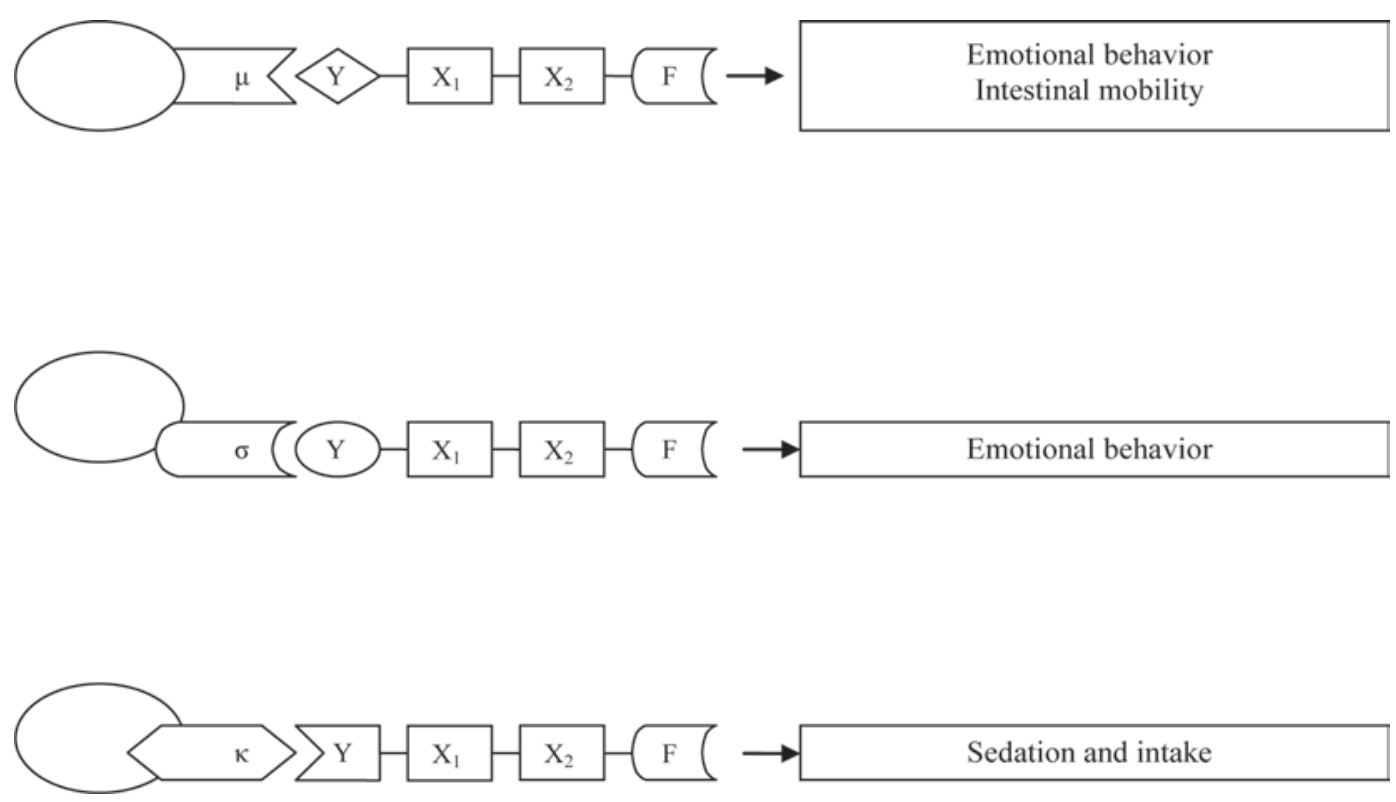

Figure 5. Action of atypical opioid peptides onto specific receptors $(\sigma, \mu, \kappa)$ and physiological effects thereof. $\mathrm{X}_{1}$ and $\mathrm{X}_{2}$ represent generic endo amino acid residues.

C-terminus yielded a peptide with even stronger bactericidal activity against the gram-negative bacteria Escherichia coli and Bordetella bronchiseptica, but a significantly reduced antibacterial capacity resulted toward B. subtilis. After a database search centered on this sequence, a high degree of homology was found with opsin, f(55-64), a human blue-sensitive peptide that is responsible for color discrimination. A peptide with this sequence was synthesized in vitro and assayed for bactericidal activity; it was strongly active against several bacterial strains (Pellegrini et al., 2000).

Hydrolysis of whey proteins has been proven to alter the biological activity of the proteins with respect to their ability to change immune system (immunomodulation). Two synthetic peptides, YG and YGG, corresponding to $\mathrm{f}(50-51)$ and $\mathrm{f}(18-20)$ of $\alpha-\mathrm{LA}$, respectively, enhanced both in vitro proliferation and protein synthesis of concanavalin A-stimulated human peripheral blood lymphocytes (Kayser and Meisel, 1996). In vitro proliferation of murine spleen lymphocytes was stimulated by microfiltered whey protein isolates, and production of $\operatorname{IgG}$ was enhanced by purified $\beta$-LG, but such effects were reduced following hydrolysis by a trypsin-chymotrypsin mixture (Wong et al., 1998; Mercier et al., 2004). Recently, whey peptide fractions derived from trypsin-chymotrypsin digestion of whey protein isolates were shown to modulate components of the immune response of a noninfected and $E$. coliinfected murine model, inducing increases in IgA in the absence of infection (Saint- Sauveur et al., 2009).
Whey proteins also induce oral tolerance: $\beta$-LG (mainly) and peptides obtained from enzymatic hydrolysis of whey proteins (e.g., tryptic peptides of bovine $\beta$-LG) are able to induce oral tolerance in mice (Pecquet et al., 2000). Oral tolerance is the mucosal and systemic antigen-specific immunological unresponsiveness caused by oral administration of a dietary antigen, which will prevent the digestive $\mathrm{IgE}$-mediated hypersensitivity reactions to food antigens. Acidic peptides were further demonstrated, upon separation by isoelectric focusing of a tryptic-chymotryptic hydrolysate of $\beta-L G$, to stimulate splenocyte proliferation and IFN- $\gamma$ production in vitro (Prioult et al., 2004). However, hydrolysis of this peptide fraction brought about by Lactobacillus paracasei peptidases repressed lymphocyte stimulation, upregulated IL-10 production, and downregulated IFN- $\gamma$ and IL-4 secretion. The authors thus concluded that $L$. paracasei apparently induces in vivo oral tolerance to $\beta-L G$ by degrading acidic peptides and releasing immunomodulatory peptides that stimulate regulatory $\mathrm{T}$ cells, which function as major immunosuppressive agents, via secretion of IL-10 (Prioult et al., 2004).

The synthetic peptide GLF, corresponding to $\mathrm{f}(51-$ 53) of $\alpha$-LA, significantly increased phagocytosis of sheep red blood cells by murine peritoneal macrophages and protected mice against lethal Klebsiella pneumonia infections (Berthou et al., 1987). This peptide also stimulated, in a dose-dependent manner, binding of human senescent red blood cells to human monocyticmacrophage cells, as well as phagocytosis by the latter 
Table 4. Peptides obtaind

\begin{tabular}{|c|c|c|c|}
\hline Enzyme & Peptide & $\begin{array}{l}\text { Amino acid } \\
\text { sequence }\end{array}$ & Identity \\
\hline $\begin{array}{l}\text { Pepsin or } \\
\text { chymosin }\end{array}$ & Lactoferricin B & $f(17-41 / 42)$ & FKCRRWQWRMKKLGAPSICVRRAF/A \\
\hline Chymosin & & $\mathrm{f}(1-16) \mathrm{S}-\mathrm{S}(17-48)$ & $\begin{array}{l}\text { APRKNVRWCTISQPEWFKCRRWQWRMKKLGAPSITCVRRAF } \\
\text { ALECIRA }\end{array}$ \\
\hline Pepsin & & $\mathrm{f}(1-16) \mathrm{S}-\mathrm{S}(45-48)$ & APRKNVRWCTISQPEWCIRA \\
\hline Pepsin & & $\mathrm{f}(1-11) \mathrm{S}-\mathrm{S}(17-47)$ & APRKNVRWCTIFKCRRWQWRMKKLGAPSITCVRRAFALECIRA \\
\hline Synthetic & & $\mathrm{f}(17-30)$ & FKCRRWQWRMKKLG \\
\hline Synthetic & & $f(19-37)$ & CRRWQWRMKKLGAPSICV \\
\hline Pepsin & Lactoferricin $\mathrm{C}$ & Goat $\mathrm{f}(14-42)$ & $\begin{array}{l}\text { PEWSKCYQWQRRMRKLGAPSITCVRRTSARRWQWRMKKLGA } \\
\text { PSICVALRA }\end{array}$ \\
\hline Synthetic & & Goat $\mathrm{f}(17-41)$ & SKCYQWQRRMRKLGAPSITCVRRTS \\
\hline Synthetic & Lactoferricin M & Murine $\mathrm{f}(17-41)$ & EKCLRWQNEMRKVGGPPLSCV \\
\hline Synthetic & Lfpep & Human $\mathrm{f}(118-140)$ & TKCFQWQRNMRKVRGPPVSCIKR \\
\hline Synthetic & Kaliocin-1 & Human f(153-183) & FFSASCVPGADKGQFPNLCRLCAGTGENKCA \\
\hline Synthetic & & $\begin{array}{l}\text { Human lysozyme } \\
\mathrm{f}(87-115)\end{array}$ & DNIADAVACAKRVVRDPQGIRAWVAWRNR \\
\hline Synthetic & Lactoferrampin & $f(268-284)$ & WKLLSKAQEKFGKNKRS \\
\hline
\end{tabular}

Antimicrobial activity References

Gram-positive and

bacteria

Bellamy et al. (1992a,b)

Bellamy et al. (1992

Recio and Visser (1999)

Escherichia coli

Hoek et al. (1997)

Micrococcus flavus

M. flavus

Recio and Visser (1999)

Recio and Visser (1999)

Oral pathogenic Groenink et al. (1999)

bacteria

Oral pathogenic

bacteria

Recio and Visser (1999)

E. coli

Staphylococcus

aureus, E. coli

Candida albicans

C. albicans

Gram-positive

and gram-negative

bacteria

C. albicans, E. coli,

Bacillus subtilis

and Pseudomonas

aeruginosa

Vorland et al. (1999)

Ibrahim et al. (2000)

van der Kraan

et al. (2004)

van der Kraan

et al. (2005) 
(Gattegno et al., 1988). This activity correlates well with the presence of specific binding sites on human blood phagocytic cells (Jaziri et al., 1992).

The antimicrobial activity and immunostimulatory activity of hydrolysates of $\alpha-\mathrm{LA}$ and $\beta-\mathrm{LG}$ have been shown to act jointly (Biziulevicius et al., 2006). These hydrolysates not only stimulated the autolytic system of naturally autolysing and some naturally nonautolysing microbial strains, but also increased the phagocytic ability of peritoneal macrophages in mice after oral administration, thus suggesting a relationship between both activities.

\section{Peptides from $\mathrm{k}$-Casein}

Glycomacropeptide is found in sweet (but not acid) whey and is released when chymosin (the main enzyme of rennet) acts on $\kappa$-casein in the preliminary cheesemaking step that eventually leads to $\alpha_{S^{-}}$and $\beta$-casein precipitation. Such a peptide corresponds to the (hydrophilic) C-terminal portion of its substrate molecule and contains oligosaccharides that are $O$-linked to $\mathrm{T}$ and $\mathrm{S}$ residues. Glycomacropeptide is composed of $64 \mathrm{AA}$ residues, with an overall molecular weight of $6.7 \mathrm{kDa}$. A unique AA sequence is found within GMP: aromatic $\mathrm{AA}$ are absent, but the sequence is rich in branchedchain AA. The degree of glycosylation of GMP is variable and influenced by the stage of lactation of the producing female and the genetic phenotype of $\kappa$-casein (Dziuba and Minkiewicz, 1996); its molecular properties have been reviewed to some length (Dziuba and Minkiewicz, 1996; el-Salam et al., 1996).

The metabolic activity of GMP is thought to depend on the content and structure of its sugar moieties, which participate in stabilization of the whole k-casein complex. The 2 most important carbohydrate components are $\mathrm{N}$-acetylneuraminic acid and $\mathrm{N}$-acetylgalactosamine (Brody, 2000). The cleavage sites of various enzymes on the C-terminal part of bovine GMP were studied by Dziuba and Minkiewicz (1996). The pathway followed by the carbohydrate moieties, which eventually determine the biological function of GMP, is still not well understood; in fact, smaller sugar-free peptides released by trypsin and chymotrypsin cannot preserve the biological function of the original GMP.

In vitro approaches have indicated that GMP prevents adhesion of cariogenic bacteria to tooth surfaces, thus suggesting that such a whey peptide is capable of inhibiting dental plaque and caries buildup (Schupbach et al., 1996). It has also been shown (Neeser et al., 1988) that GMP decreases the extent of bacterial adhesion of actinomycetes and streptococci, the binding of cholera toxin to its receptor (Kawasaki et al., 1992), and the binding of the heat-labile enterotoxins LT-I and LT-II of E. coli. This glycoprotein exhibits antiviral activity against hemagglutinin from the influenza virus (Kawasaki et al., 1993). Most studies of the biological activity of GMP were done in vitro, so they will eventually require in vivo validation.

Proliferation and phagocytic activities (via incorporation of fluorescent beads) of human macrophage-like cells (U937) were significantly enhanced in the presence of GMP (Li and Mine, 2004). Furthermore, digestion of GMP with pepsin led to higher proliferation and phagocytic activities, indicating that the enhanced immunostimulatory effect of GMP is due mainly to pepsin-digested fragments of it; Li and Mine (2004) also showed that both the carbohydrate and the polypeptide chain compositions of GMP are essential for such stimulating effects to occur.

\section{Peptides from Lactoferrin}

Lactoferrin (LF) derivatives deserve special mention among whey peptides with antimicrobial activity. To date, the 2 most-studied lactoferricins (LFcin) are those derived from bovine and human LF (BLFcin and HLFcin, respectively). The 25-residue bovine peptide (f17-41) of LF is a more potent antimicrobial compound than its 47-residue counterpart derived from human LF (Facon and Sakura, 1996).

Several biological properties have been claimed for BLFcin (Wakabayashi et al., 2003). It possesses antimicrobial activity against gram-negative and grampositive bacteria and yeasts, as described in Tables 4 and 5 (Shin et al., 1998; Lupetti et al., 2000); however, some strains of Streptococcus lactis and Lactobacillus casei proved resistant to BLFcin (Korhonen, 2001). It has several putative modes of action: 1) cell surface binding (e.g., to E. coli and B. subtilis) (Bellamy et al., 1993); 2) damage in cell bacteria via membrane disruption, and in fungi via changes in ultrastructural features (Yamauchi et al., 1993); 3) release of LPS, and consequent disruption of the outer membrane (Kang et al., 1996); 4) interaction (of a BLFcin 11-residue peptide) with bacterial phospholipid membranes (Jack et al., 1998); 5) disruption of essential cell-membrane functions via formation of ion channels in artificial membranes (Samuelsen et al., 2004); and 6) effects in the cytoplasm contents and consequent action upon the cell surface (Shin et al., 1998). Bovine LFcin lacks the iron-binding region of its source protein, BLF, so it follows a different antimicrobial mechanism.

Bovine LFcin, like LF, possesses immunomodulating and anti-inflammatory properties; it apparently inhibits the classical complement pathway and reduces the inhibitory properties of serum against E. coli in a concentration-dependent manner (Samuelsen et al., 
Table 5. Specific targets of antimicrobial features of lactoferricin and lactoferrampin both derived from lactoferrin hydrolysis

\begin{tabular}{|c|c|}
\hline $\begin{array}{l}\text { Peptide and antimicrobial } \\
\text { activity target }\end{array}$ & Reference \\
\hline \multicolumn{2}{|l|}{ Lactoferricin } \\
\hline \multicolumn{2}{|l|}{ Gram-negative } \\
\hline Escherichia coli $\mathrm{O} 157: \mathrm{H} 7$ & Shin et al. (1998); Bellamy et al. (1992a,b); Tomita et al. (1992) \\
\hline Salmonella spp. & Dionysius and Milne (1997) \\
\hline Klebsiella pneumoniae & Shin et al. (1998); Bellamy et al. (1992a) \\
\hline Yersinia enterocolitica & Bellamy et al. (1992a) \\
\hline Pseudomonas aeruginosa & Yamauchi et al. (1993); Bellamy et al. (1992a,b) \\
\hline \multicolumn{2}{|l|}{ Gram-positive } \\
\hline Listeria monocytogenes & Bellamy et al. (1992b) \\
\hline Bacillus spp. & Shin et al. (1998); Bellamy et al. (1992a) \\
\hline Clostridium spp. & Bellamy et al. (1992a) \\
\hline Corynebacterium spp. & Bellamy et al. (1992a) \\
\hline Enterococcus faecalis & Bellamy et al. (1992a) \\
\hline Streptococcus spp. & Bellamy et al. (1992a) \\
\hline \multicolumn{2}{|l|}{ Yeasts } \\
\hline Candida albicans & Viejo-Díaz et al. (2005); Bellamy et al. (1992b) \\
\hline Trichosporum cutaneum & Bellamy et al. (1994) \\
\hline \multicolumn{2}{|l|}{ Dermatophytes } \\
\hline Trychophyton spp. & Bellamy et al. (1994) \\
\hline Nannizzia spp. & Bellamy et al. (1994) \\
\hline \multicolumn{2}{|l|}{ Other filamentous fungi } \\
\hline Aspergillus spp. & Bellamy et al. (1994) \\
\hline Penicillium spp. & \\
\hline \multicolumn{2}{|l|}{ Parasites } \\
\hline Toxoplasma gondi & Bellamy et al. (1994) \\
\hline \multicolumn{2}{|l|}{ Viruses } \\
\hline Human cytomelogalovirus & Andersen et al. (2001) \\
\hline Hepatitis $\mathrm{C}$ virus & Ikeda et al. (2000) \\
\hline Herpes simplex virus 1 and 2 & Andersen et al. (2001) \\
\hline Feline calcivirus & McCann et al. (2003) \\
\hline Adenovirus & di Biase et al. (2003) \\
\hline Echovirus & Pietrantoni et al. (2006) \\
\hline \multicolumn{2}{|l|}{ Lactoferrampin } \\
\hline Escherichia coli & van der Kraan et al. (2004) \\
\hline Pseudomonas aeruginosa & \\
\hline Bacillus subtilis & \\
\hline Candida albicans & \\
\hline
\end{tabular}

2004). However, no inhibitory effect was observed on the alternative complement pathway by other authors (Mattsby-Balzer et al., 1996; Vorland et al., 1999); this was explained by the capacity of BLFcin to inhibit LPSinduced cytokine response in human monocytic cells.

Lactoferricin exhibits a synergistic capacity with antifungal compounds such as azole agents (Wakabayashi et al., 1996). Lactoferricin also exerts antiviral activity (Table 5) against human cytomegalovirus and is able to inhibit actual invasion thereby (Andersen et al., 2001). Bovine LF is more effective than BLFcinB against herpes simplex virus 1 and 2 (Andersen et al., 2003), suggesting that the native protein possesses other regions that contribute to the aforementioned phenomenon (Siciliano et al., 1999; Hammer et al., 2000); this higher activity was also observed toward hepatitis C virus (Ikeda et al., 2000). Furthermore, BLFcin was demonstrated (Shimazaki et al., 1998) to bind glycosaminoglycans, heparin in particular.
The N-acylated, D-enantiomer peptide derivatives of BLFcin are believed (Wakabayashi et al., 1999) to possess antimicrobial activities greater than those of the native peptide against both bacteria and fungi; the most potent peptide, conjugated with an 11-carbon chain-acyl group, showed 2 to 8 times lower MIC than BLFcin.

Several other LF-derived peptides exist (Table 5), indicating that LF hydrolysates besides LFcins may yield a number of antimicrobial peptides against various bacteria.

Two synthetic peptides from human LF were described (Viejo-Díaz et al., 2005): Lfpep, a cationic peptide with bactericidal and giardicidal effects, and kaliocin-1, a novel bactericidal peptide that shares the highly homologous sequence with the transferrin family of proteins (Table 4). Both proteins possess fungicidal activity against Candida spp. The killing activity of LFpep on Candida albicans is mediated by its permea- 
bilizing activity, whereas kaliocin-1 is unable to disrupt the cytoplasmatic membrane - as indicated by its inability to allow permeation of propidium iodide, and by the small amount of $\mathrm{K}^{+}$released.

Lactoferrampin (BLFampin) was recently identified in the N1-domain of BLF, and a primary structure close to that of BLFcinB was reported (Vogel et al., 2002; Table 5). Besides BLFampin, several shorter peptides have been studied (van der Kraan et al., 2004). The peptide $\mathrm{f}(265-284)$ of BLFampin possesses a higher activity than the original BLFampin against yeasts, probably because of its higher propensity to adopt an Q-helical conformation (Schmidt et al., 1984). Lactoferrampin peptide $\mathrm{f}(265-284)$ and $\mathrm{BLF}$ cinB $\mathrm{f}(17-30)$ can be translocated across the membranes of $C$. albicans and $E$. coli to exhibit large effects upon their plasma membrane integrity, such as induction of distinct vesicle-like structures in the membrane by BLFampin, and detachment of the outer membrane and emergence of surface protrusions in the latter by BLFcin B; this peptide also showed a particularly strong effect against pathogenicity of E. coli.

\section{PEPTIDES WITH NUTRITION SYSTEM ACTIVITIES}

Hydrolysis of proteins in general, and of whey proteins in particular, has been shown to improve digestibility (and to better regulate the digestive process), as well as specifically decrease cholesterol levels. Improvement of digestibility is beneficial for patients who suffer from digestion disorders such as cystic fibrosis, short bowel syndrome, or pancreatitis, and that improvement may easily be achieved via (nonspecific) hydrolysis of whey proteins (Yvon et al., 1994).

\section{Peptides from GMP}

The protein source has been evaluated for its effect on satiety and food intake in humans. Glycomacropeptide can, in particular, act as a regulator of the digestive function without being absorbed (Yvon et al., 1994). This conclusion was reached upon injection of GMP, which led to suppression of gastric secretions (Chernikov et al., 1974); the active components were peptides formed via breakdown of GMP effected by pepsin (at the low pH typically prevailing in the stomach). Glycomacropeptide suppresses gastric digestion and promotes satiety by induction of cholecystokinin, which is a hormone that regulates energy and food intake by intestinal cells; it also stimulates gall bladder contraction and bowel motility, regulates gastric emptying, and stimulates release of enzymes by the pancreas (Beucher et al., 1994). The proposed regulation of food intake mechanisms is depicted in Table 3.
Glycomacropeptide can be included in diets aimed at controlling various liver diseases, in which branchedchain AA residues are used as a carbon source (el-Salam et al., 1996). The short-term effect of mixtures of whey protein and GMP versus a carbohydrate control on satiety in healthy adult humans has been assessed (Lam et al., 2009). There is some evidence that whey proteins and their components enhance satiety over a short-term period compared with carbohydrate, but there was no consistent effect of whey protein either alone or coupled with GMP.

The most important nutritional role that has been associated with GMP derives from its use as an ingredient in diets designed for people suffering from phenylketonuria (Smithers et al., 1996); these patients are unable to metabolize $\mathrm{F}$ and therefore must ingest diets free of Phe (GMP lacks F). In particular, a peptide-fortified fruit gel low in $\mathrm{F}$, and targeted at these individuals, was successfully developed (Marshall, 1991).

\section{Peptides from Other Sources}

Several dietary proteins have been shown to influence serum cholesterol levels (Zhang and Beynen, 1993; Potter, 1995); however, few data concern the effect of derivatives of whey proteins on cholesterol metabolism. A hypocholesterolemic peptide (IIAQK) derived from $\beta$-LG can act effectively on serum cholesterol levels to an extent above that of $\beta$-sitosterol (Nagaoka et al., 2001). $\beta$-Lactotensin showed hypocholesterolemic activity after administration to mice for $2 \mathrm{~d}$ at a dose of $30 \mathrm{mg} / \mathrm{kg}$ i.p. or $100 \mathrm{mg} / \mathrm{kg}$ p.o. (Yamauchi et al., 2003a).

The effect of albutensin $\mathrm{A}$ on food intake in mice was also studied (Table 3); this peptide delays gastric emptying and elevates blood glucose levels (Ohinata et al., 2002), so it may eventually be used in human diets to promote weight loss and prevent obesity.

Finally, hydrolysis can be applied to destroy protein epitopes responsible for allergic reactions in sensitive individuals; for example, infants suffering from cow's milk protein allergy (Boza et al., 1995; Martin-Esteban et al., 1998; Halken et al., 2000); this general feature may also be taken advantage of in the case of whey peptides.

\section{OTHER PEPTIDES WITH BIOACTIVITIES}

In contrast to the basic whey protein fractions, little is known on the possible benefits of the acidic whey protein fractions. The acidic (i.e., low isoelectric point) protein component of whey is known to contain phosphorylated proteins and peptides (Sorensen and Petersen, 1993; Reid et al., 2004), some of which may 
play a role in calcium absorption. Additionally, the whey acidic protein complement contains osteopontin and likely fragments of it (e.g., free potassium; K. P. Palmano, LactoPharma, Fonterra Research Center, Palmerston North, New Zealand; unpublished data), which are essential to bone mineralization (Bayless et al., 1997; Denhardt and Noda, 1998). An acidic protein fraction isolated from mineral acid whey protein concentrate was recently shown to have antiresorptive effects in vitro (Reid et al., 2004); such a fraction also exhibited bone bioactivity in vivo in ovariectomized rat (Kruger et al., 2005).

The proteose-peptone component 3 (PP3) is a phosphorylated glycoprotein isolated from bovine milk, but usually released only in whey (Sorensen and Petersen, 1993); it is also known as lactophoricin. It comprises a polypeptide backbone of 135 AA residues (including 5 phosphorylated S residues, 2 T-linked $O$-glycosylations, and $1 \mathrm{~N}$-glycosylation site; it has been cloned, and its cDNA sequence has been determined (Johnsen et al., 1995). The exact function of PP3 in vivo is still unresolved; however, several studies (Girardet et al., 1993) have shown that PP3 has the ability to inhibit lipoprotein lipase activity, thus suggesting a potential role as inhibitor of spontaneous lipolysis in milk. Immunological studies found PP3 residues in the milk fat globule membrane and have shown that PP3 forms multimeric aggregates in bovine whey (Sorensen et al., 1997).

Considering the pore-forming ability of the $\mathrm{f}(113-135)$ C-terminal peptide of bovine PP3, it is conceivable that this peptide interacts with natural lipidic bilayers, such as bacterial membranes. Antimicrobial and hemolytic assays were therefore carried out, using the corresponding synthetic peptide; it presented inhibitory growth activity against both gram-negative and gram-positive bacteria, but no hemolytic activity in the concentration range tested (<200 $\mu M$; Campagna et al., 2004).

\section{STABILITY OF BIOACTIVE PEPTIDES}

Following oral ingestion, milk components are digested and eventually absorbed in the gastrointestinal tract (Figure 1). Digestion of proteins is initiated in the stomach and is normally brought about by pepsin under the strongly acidic conditions prevailing in that organ. After this step, the digestion products are further hydrolyzed by pancreatic enzymes such as trypsin and chymotrypsin, as well as by membrane peptidases (Tomé and Ledoux, 1998). Gastrointestinal digestion depends upon availability of ACE-inhibitory peptides; proteases present in the gastrointestinal tract may hydrolyze such peptides and thus alter their activity. Research experiments have been conducted that simulate gastrointestinal digestion, from batch dialysis bags (Gauthier et al., 1986; Pihlanto-Leppälä et al., 1998; Oomen et al., 2002) to more complex computercontrolled models, including artificial stomachs (Yvon et al., 1992), the TIM gastrointestinal tract model (Minekus et al., 1995), the SHIME model (simulator of the human intestinal microbial ecosystem; Molly et al., 1993), and models coupled to cell culture (Glahn et al., 2002). Some of them use pancreatin as a small intestine enzyme source, whereas others resort to relatively pure trypsin and chymotrypsin.

To exert their physiological effects in vivo, bioactive peptides have to reach their target sites at the luminal side of the intestinal tract or at specific peripheral organs following absorption (Meisel and Schlimme, 1996; Langley-Danysz, 1998; Meisel, 1998). There is considerable evidence suggesting that intact proteins and peptide fragments can enter the blood circulation to reach physiologically important levels (Mills et al., 1992). However, some peptides exhibit bioactivity in vitro but are ineffective in vivo, which suggests gastrointestinal degradation. Some researchers have identified potent in vitro ACE-inhibitory activity for some milk-derived peptides that cannot exert antihypertensive effects in vivo (Maruyama et al., 1987; Maeno et al., 1996; Abubakar et al., 1998; Saito et al., 2000). Another example is $\beta$-LG $\mathrm{f}(142-148)$; despite reports that it can be transported intact across Caco- $2 \mathrm{~b}$ cell monolayers (Vermeirssen et al., 2002), recent studies (Walsh et al., 2004; Roufik et al., 2006) have shown that this peptide is degraded during (simulated) gastrointestinal digestion. Its stability was further tested (Walsh et al., 2004), so we can conclude that it is not sufficiently stable in vivo to gastrointestinal and serum proteinases and peptidases (e.g., pepsin and colorases), and that it is unable to exhibit ACE-inhibiting activity in vivo. Afterwards, peptides $\beta$-LG $\mathrm{f}(15-20), \mathrm{f}(102-105)$, and $\mathrm{f}(142-148)$, known for their biological activities (Table 1 ), were tested for stability during digestion (Roufik et al., 2006). When incubated with pepsin, $\mathrm{f}(142-148)$ remained intact, whereas $\beta$-LG f $(15-20)$ and $\mathrm{f}(102-105)$ were hydrolyzed to some extent (less than $31 \%$ ); conversely, chymotrypsin hydrolyzed $\beta$-LG f(142-148) up to $99.8 \%$. Furthermore, peptides obtained by fermentation sometimes exert higher ACE-inhibitory activity following in vitro digestion; for example, whey protein fermented by Saccharomyces cerevisiae (Sorensen and Petersen, 1993). These results suggest that lactokinin $\beta$-LG f (142-148) and other bioactive peptides may need protection against gastric or intestinal enzymatic degradation in order for their physiological effects be fully displayed in vivo. 


\section{PROTEIN-PEPTIDE INTERACTIONS}

The interactions of peptides with proteins have been shown to induce changes in the conformation of the target protein, which enhances its resistance to some aggressive processes. There are 2 types of interactions: 1) specific interactions, which include peptide interaction with a protein membrane receptor for propagation of information through a signaling system, inhibition of an enzyme with a peptide, and formation of molecular complexes - this process may play an important role in a wide range of biological processes; and 2) nonspecific protein-peptide interactions, which are observed in food systems. Such interactions apply mainly to protein hydrolysates that consist of mixtures of intact protein and peptides.

Hydrolysates of a whey protein isolate brought about by a seryl protease from Bacillus licheniformis could aggregate nonhydrolyzed whey proteins; these peptides have apparent molecular weights ranging from 1,400 to $7,500 \mathrm{Da}$ (under reducing conditions). Such proteinpeptide interactions depend on a balance between hydrophobic attraction and electrostatic repulsion (Creusot and Gruppen, 2006).

$\beta$-Lactoglobulin was shown to interact with whey peptide fractions, thus increasing their resistance to thermodenaturation (Barbeau et al., 1996). Whole protein (in a zymogen-like vector) was suggested as a carrier to protect the bioactive peptides from gastric digestion (Gauthier and Pouliot, 2003). Study of peptide-peptide and peptide-protein interactions during fractionation of hydrolysates by nanofiltration, aiming at recovery of specific peptide fractions, led these authors to conclude that the opioid peptide $\mathrm{f}(102-105)$ binds to the inner cavity of $\beta$-LG. Furthermore, interaction between $\beta$-LG and its daughter peptide $\mathrm{f}(142-148)$ was hypothesized (Roufik et al., 2006, 2007); $\beta$-LG f(142-148) was able to bind inside the hydrophobic calyx of the protein or near the interface of the dimer. In vitro chymotryptic hydrolysis of $\beta$-LG A to peptide complexes suggested that hydrolysis during gastrointestinal digestion can be delayed, hence allowing delivery of intact lactokinin $\beta$-LG f(142-148) closer to the sites of intestinal absorption (Roufik et al., 2007).

$\alpha$-Lactalbumin is known to interact with peptides containing clusters of basic amino acid residues in close proximity with hydrophobic amino acid ones (Gurgel et al., 2001) such as melittin, a 26-residue cytolytic peptide from bee venom. The binding of $\alpha$-lactalbumin to the synthetic peptide WHWRKR was used to develop a purification strategy for that protein.
FINAL REMARKS

Use of selective membranes to isolate and eventually purify whey proteins has substantially increased the number and the depth of studies encompassing those molecules and their hydrolysates. Most whey peptides bearing biological activity are released by enzymatic hydrolysis, but microbial fermentation can also be used for this purpose. Increasing availability of whey protein concentrates in the market and generalization of fermentation technology has helped promote interest in production of bioactive peptides by microbial fermentation as an alternative to enzymatic routes.

Many new products with bioactive peptides have been launched in the market. There is a growing body of evidence that whey peptides exhibit physiological activities on specific components of the immune response system. In addition, ACE-inhibitory whey peptides can play roles in blood pressure regulation and hypertension; unfortunately, a high ACE-inhibiting activity in vitro does not necessarily correlate with a high antihypertensive activity in vivo. Release of peptides with high ACE-inhibiting activity is not limited by the protein and enzyme sources, but the highest activities are typically found in peptides released by trypsin.

Differences in methodologies, in the nature of raw materials, and in model systems have led to several disparate results. Hence, conclusions drawn from in vitro models need to be consistently validated with physiological data obtained in vivo, so that the potential of whey peptides in immunomodulation can be fully demonstrated.

For a candidate peptide to be labeled as bioactive, its resistance to gastrointestinal conditions must be determined in advance. The exact mechanisms by which whey peptides exert their bioactivities upon reaching the intestine need further elucidation; for example, whether their effect is mediated directly in the gut lumen or through receptors on the intestinal cell wall. Therefore, in vivo studies are essential not only to validate the physiological effects of tentative bioactive peptides, but also to confirm whether they will require protection from gastrointestinal enzymes when orally administered.

Future research should focus on novel hydrolysis pathways for breakdown of whey proteins and peptides, brought about by unusual proteases aimed at releasing unique amino acid sequences; these might include enzymes from the native microbiota of dairy products or from plant rennets. Furthermore, molecular studies concerning the mechanisms by which bioactive peptides exert their activities are to be undertaken. 


\section{ACKNOWLEDGMENTS}

Partial funding for this research work was provided via project PROBIOSORO, coordinated by F. X. Malcata and administered by Agência de Inovação POCTI: Programa Operacional de Ciência, Tecnologia e Inovação. Funding for A. R. Madureira and T. Tavares was via $\mathrm{PhD}$ fellowships supervised by $\mathrm{F}$. X. Malcata and administered by Fundação para a Ciência e a Tecnologia (refs. SFRH/BD/18500/2004 and SFRH/ $\mathrm{BD} / 31604 / 2006)$.

\section{REFERENCES}

Abubakar, A., T. Saito, H. Kitazawa, Y. Kawai, and T. Itoh. 1998. Structural analysis of new antihypertensive peptides derived from cheese whey protein by proteinase K digestion. J. Dairy Sci. 81:3131-3138.

Andersen, J. H., H. Jenssen, and T. J. Gutterberg. 2003. Lactoferrin and lactoferricin inhibit Herpes simplex 1 and 2 infection and exhibit synergy when combined with acyclovir. Antiviral Res. $58: 209-215$.

Andersen, J. H., S. A. Osbakk, L. H. Vorland, T. Travik, and T. J. Gutterberg. 2001. Lactoferrin and cyclic lactoferricin inhibit the entry of human cytomelogavirus into human fibroblasts. Antiviral Res. 51:141-149.

Antila, P., I. Paakkari, A. Järvinen, M. J. Mattila, M. Laukkanen, A. Pihlanto-Leppälä, P. Mäntsälä, and J. Hellman. 1991. Opioid peptides derived from in vitro proteolysis of bovine whey proteins. Int. Dairy J. 1:215-229.

Barbeau, J., S. F. Gauthier, and Y. Pouliot. 1996. Thermal stabilization of $\beta$-lactoblobulin by whey peptide factions. J. Agric. Food Chem. 44:3939-3945.

Baró, L., J. Jiménez, A. Martínez-Férez, and J. Bouza. 2001. Bioactive milk peptides and proteins. Ars Pharmaceutica 42:135-145.

Bayless, K. J., G. E. David, and G. A. Meininger. 1997. Isolation and biological properties of osteopontin from bovine milk. Protein Expr. Purif. 9:309-314.

Bellamy, W., M. Takase, H. Wakabayashi, K. Kawase, and M. Tomita. 1992b. Antibacterial spectrum of lactoferricin B, a potent bactericidal peptide derived from the N-terminal region of bovine lactoferrin. J. Appl. Bacteriol. 73:472-479.

Bellamy, W., M. Takase, K. Yamauchi, H. Wakabayashi, K. Kawase, and M. Tomita. 1992a. Identification of the bactericidal domain of lactoferrin. Biochim. Biophys. Acta 1121:130-136.

Bellamy, W., H. Wakabayashi, M. Takase, K. Kawase, S. Shimamura, and M. Tomita. 1993. Role of cell binding in the antibacterial mechanism of lactoferricin B. J. Appl. Bacteriol. 75:478-484.

Bellamy, W., K. Yamauchi, H. Wakabayashi, M. Takase, N. Takakura, and S. Shimamura. 1994. Antifungal properties of lactoferricin B, a peptide derived from the N-terminal region of bovine lactoferrin. Lett. Appl. Microbiol. 18:230-233.

Berthou, J., D. Migliore-Samour, A. Lifchitz, J. Delettre, F. Floch, and P. Jolles. 1987. Immunostimulating properties and threedimensional structure of two tripeptides from human and cow caseins. FEBS Lett. 218:55-58.

Beucher, M., F. Levenez, Y. Yvon, and T. Corring. 1994. Effect of caseinomacropeptide (CMP) of cholecystokinin (CCK) release in rats. Reprod. Nutr. Dev. 34:613-614.

Biziulevicius, G. A., O. V. Kislukhina, J. Kazlauskaite, and V Zukaite. 2006. Food-protein enzymatic hydrolysates possess both antimicrobial and immunostimulatory activities: A "cause and effect" theory of bifunctionality. FEMS Immunol. Med. Microbiol. $46: 131-138$.

Bordenave, S., F. Sannier, G. Ricart, and J. M. Piot. 1999. Continuous hydrolysis of goat whey in an ultrafiltration reactor: Generation of alpha-lactorphin. Prep. Biochem. Biotechnol. 29:189-202.
Boza, J. J., O. Martínez-Augustin, and A. Gil. 1995. Nutritional and antigenic characterization of an enzymatic whey protein hydrolysate. J. Agric. Food Chem. 43:872-875.

Brody, E. P. 2000. Biological activities of bovine glycomacropeptide. Br. J. Nutr. 84:39-46.

Campagna, S., A.-G. Mathot, Y. Fleury, J.-M. Girardet, and J.-L. Gaillard. 2004. Antibacterial activity of lactophoricin, a synthetic 23-residue peptide derived from the sequence of bovine milk component-3 of proteose peptone. J. Dairy Sci. 87:1621-1626.

Cassens, P. W. J. R., S. Visser, H. Gruppen, and A. G. J. Voragen. 1999. $\beta$-Lactoglobulin hydrolysis. 1. Peptide composition and functional properties of hydrolysates obtained by the action of plasmin, trypsin, and Staphylococcus aureus V8 protease. J. Agric. Food Chem. 47:2973-2979.

Chernikov, M. P., G. V. Nikolskaya, E. Y. Stan, G. K. Shlygun, and L. S. Vasilevskaya. 1974. Biological role of $\kappa$-casein glycomacropeptide. Vopr. Pitan. 2:21-25.

Cheung, H. S., F. L. Wang, M. A. Ondetti, E. F. Sabo, and D. W Cushman. 1980. Binding of peptide substrates and inhibitors of angiotensin-converting enzyme. Importance of the $\mathrm{COOH}$-terminal dipeptide sequence. J. Biol. Chem. 225:401-407.

Chiba, H., and M. Yoshikawa. 1991. Bioactive peptides derived from food proteins. Kagaku To Seibutsu 29:454-458.

Creusot, N., and H. Gruppen. 2006. Enzyme-induced aggregation and gelation of proteins. Biotechnol. Adv. 25:597-601.

Denhardt, D. T., and M. Noda. 1998. Osteopontin expression and function: Role in bone remodelling. J. Cell. Biochem. 30-31:92102.

di Biase, A. M., A. Pietrantoni, and A. Tinari. 2003. Heparin-interacting sites of bovine lactoferrin are involved in anti-adenovirus activity. J. Med. Virol. 69:495-502.

Didelot, S., S. Bordenave-Juchereau, E. Rosenfeld, J.-M. Piot, and F. Sannier. 2006. Peptides released from acid goat whey by a yeastlactobacillus association isolated from cheese microflora. J. Dairy Res. 6:163-170.

Dionysius, D. A., and J. M. Milne. 1997. Antibacterial peptides of bovine lactoferrin 494: Purification and characterization. J. Dairy Sci. 80:667-674.

Dziuba, J., and P. Minkiewicz. 1996. Influence of glycosylation on content of both micelle-stabilizing ability and biological properties of the C-terminal fragments of cow's k-casein. Int. Dairy J. $6: 1017-1044$.

el-Salam, A. M. H., S. el-Shibiny, and W. Buchheim. 1996. Characteristics and potential uses of the casein macropeptide. Int. Dairy J. 6:327-341.

Facon, M. J., and B. J. Sakura. 1996. Antibacterial activity of lactoferricin, lysozyme and EDTA against Salmonella enteritidis. Int. Dairy J. 6:303-313.

FitzGerald, R. J., and H. Meisel. 1999. Lactokinins: Whey proteinderived ACE inhibitory peptides. Nahrung/Food 43:165-167.

Gattegno, L., D. Migliore-Samour, L. Saffar, and P. Jolles. 1988. Enhancement of phagocytic activity of human monocyticmacrophagic cells by immunostimulating peptides from human casein. Immunol. Lett. 18:27-31.

Gauthier, S. F., and Y. Pouliot. 2003. Functional and biological properties of peptides obtained by enzymatic hydrolysis of whey proteins. J. Dairy Sci. 86:78-87.

Gauthier, S. F., C. Vachon, and L. Savoie. 1986. Enzymatic conditions of an in vitro method to study protein digestion. J. Food Sci. 51:960-964.

Gerdes, S. K., J. W. Harper, and G. Miller. 2002. Applications Monograph: Cardiovascular Health Bioactive Components of Whey and Cardiovascular Health. The American Dairy Products Institute, US Dairy Export Council, Chicago, IL.

Girardet, J. M., G. Linden, S. Loye, J. L. Courthaudon, and D. Lorient. 1993. Study of a mechanism of lipolysis inhibition by bovine milk proteose peptone component-3. J. Dairy Sci. 76:2156-2163.

Glahn, R. P., G. M. Wortley, P. K. South, and D. D. Miller. 2002 Inhibition of iron uptake by phytic acid tannic acid and $\mathrm{ZnCl}_{2}$ : Studies using an in vitro digestion/Caco-2 cell model. J. Agric. Food Chem. 50:390-395. 
Groenink, J., E. Walgreen-Weterings, W. van 't Hof, E. C. Veerman, and A. V. N. Amerongen. 1999. Cationic amphipathic peptides, derived from bovine and human lactoferrins, with antimicrobial activity against oral pathogens. FEMS Microbiol. Lett. 179:217222 .

Grufferty, M. B., and P. F. Fox. 1988. Milk alkaline proteinase. J. Dairy Res. 55:609-613.

Gurgel, P. V., R. G. Carbonell, and H. E. Swaisgood. 2001. Identification of peptide ligands generated by combinatorial chemistry that bind $\alpha$-lactalbumin. Sep. Sci. Technol. 36:2411-2431.

Halken, S., K. S. Hansen, H. P. Jacobsen, A. Estmann, A. E. Faelling, L. G. Hansen, S. R. Kier, K. Lassen, M. Lintrup, M. Mortensen, K. K. Ibsen, O. Osterballe, and A. Host. 2000. Comparison of a partially hydrolyzed infant formula with two extensively hydrolyzed formulas for allergy prevention: A prospective randomized study. Pediatr. Allergy Immunol. 11:149-161.

Hammer, J., H. Haheim, and T. J. Gutterberg. 2000. Bovine lactoferrin is more efficient than bovine lactoferricin in inhibiting HSV-I/ II replication in vitro. Pages 239-243 in Lactoferrin: Structure, Functions, and Applications. K. Shimazaki, ed. Elsevier Science, Amsterdam, the Netherlands.

Hoek, K. S., J. M. Milne, P. A. Grieve, D. A. Dionysius, and R. Smith. 1997. Antibacterial activity of bovine lactoferrin-derived peptides. Antimicrob. Agents Chemother. 41:54-59.

Ibrahim, E. H., G. Sherman, S. Ward, V. J. Fraser, and M. H. Kollef. 2000. The influence of inadequate antimicrobial treatment of bloodstream infections on patient outcomes in the ICU setting. Chest 118:146-155.

Ijäs, H., M. Collin, P. Finckenberg, A. Pihlanto-Leppälä, H. Korhonen, P. Korpela, H. Vapaatalo, and M.-L. Nurminem. 2004. Antihypertensive opioid-like milk peptide $\alpha$-lactorphin: Lack of effect on behavioural tests in mice. Int. Dairy J. 14:201-205.

Ikeda, M., A. Nozaki, K. Sugiyama, T. Tanaka, A. Naganuma, K. Tanaka, H. Sekihara, K. Shimotohno, M. Saito, and N. Kato. 2000. Characterization of antiviral activity of lactoferrin against hepatitis $\mathrm{C}$ virus infection in human cultured cells. Virus Res. 66:51-63.

Iqbal, G., R. López-Fandiño, X. Jorba, and E. N. Vulfson. 1996. Biologically active peptides and enzymatic approaches to their production. Enzyme Microb. Technol. 18:162-183.

Jack, R. W., G. Bierbaum, and H.-G. Sahl. 1998. Lantibiotics and Related Peptides. Springer-Verlag, New York, NY.

Jaziri, M., D. Migliore-Samour, M.-R. Casabianca-Pignède, K. Keddad, J.-L. Morgat, and P. Jollès. 1992. Specific binding sites on human phagocytic blood cells for Gly-Leu-Phe and Val-GluPro-Ile-Pro-Tyr immunostimulating peptides from human milk proteins. Biochim. Biophys. Acta 1160:251-261.

Johnsen, L. B., E. S. Sùrensen, T. E. Petersen, and L. Berglund. 1995. Characterization of a bovine mammary gland PP3 cDNA reveals homology with mouse and rat adhesion molecule GlyCAM-1. Biochim. Biophys. Acta 1260:116-118.

Kang, J. H., M. K. Lee, K. L. Kim, and K.-S. Hahm. 1996. Structurebiological activity relationships of 11-residue highly basic peptide segment of bovine lactoferrin. Int. J. Pept. Protein Res. 48:357363.

Kawasaki, Y., H. Isoda, M. Tanimoto, S. Dosako, T. Idota, and K. Ahiko. 1992. Inhibition by lactoferrin and casein glycomacropeptide of binding of cholera toxin to its receptor. Biosci. Biotechnol. Biochem. 56:195-198.

Kawasaki, Y., H. Kawakami, M. Tanimoto, S. Dosako, A. Tomizawa, M. Kotake, and I. Nakajima. 1993. pH-Dependent molecular weight changes of $\kappa$-casein glycomacropeptide and its preparation by ultrafiltration. Milchwissenschaft 48:191-195.

Kayser, H., and H. Meisel. 1996. Stimulation of human peripheral blood lymphocytes by bioactive peptides derived from bovine milk proteins. FEBS Lett. 383:18-20.

Kitchen, B. J. 1985. Indigenous milk enzymes. Page 239 in Developments in Dairy Chemistry. Vol. 3 P. F. Fox, ed. Applied Science Publishers, London, UK.

Korhonen, H. 2001. Antibacterial and antiviral activities of whey proteins, the importance of whey and whey components in food and nutrition. Pages 303-321 in Proc. 3rd Int. Whey Conf., Munich, Germany.

Korhonen, H., and A. Pihlanto. 2003. Bioactive peptides and proteins. Adv. Food Nutr. Res. 47:175-176.

Kruger, M. C., G. G. Plimmer, L. M. Schollum, N. Haggarty, S. Ram, and K. Palmano. 2005. The effect of whey acidic protein fractions on bone loss in the ovariectomised rat. Br. J. Nutr. 94:244-252.

Lam, S. M., P. J. Moughan, A. Awati, and H. R. Morton. 2009. The influence of whey protein and glycomacropeptide on satiety in adult humans. Physiol. Behav. 96:162-168.

Langley-Danysz, P. 1998. Des hydrolysats protéiques pour développer des aliments santé. RIA Technol. Veille. 581:38-40.

Li, E. W., and Y. Mine. 2004. Immunoenhancing effects of bovine glycomacropeptide and its derivatives on the proliferative response and phagocytic activities of human macrophage-like cells U937. J. Agric. Food Chem. 52:2704-2708.

Lupetti, A., A. Paulusma-Annema, M. M. Welling, S. Senesi, J. T. van Dissel, and P. H. Nibbering. 2000. Candidacidal activities of human lactoferrin peptides derived from the $\mathrm{N}$ terminus. Antimicrob. Agents Chemother. 44:3257-3263.

Madureira, A. R., C. I. Pereira, A. M. P. Gomes, M. E. Pintado, and F. X. Malcata. 2007. Bovine whey proteins-Overview on the main biological properties. Food Res. Int. 40:1197-1211.

Maeno, M., N. Yamamoto, and T. Takano. 1996. Identification of an antihypertensive peptide from casein hydrolysate produced by a proteinase from Lactobacillus helveticus CP790. J. Dairy Sci. 79:1316-1321.

Maes, W., J. van Camp, V. Vermeirssen, M. Hemeryck, J. M. Ketelslegers, J. Chrezenmeir, P. van Oosteveldt, and A. Huyghebaert. 2004. Influence of the lactokinin Ala-Leu-ProMet-His-Ile-Arg (ALPMHIR) on the release of endothelin-1 by endothelial cells. Regul. Pept. 118:105-109.

Marshall, S. C. 1991. Casein macropeptide from whey-A new product opportunity. Food Res. Quart. 51:86-89.

Martin-Esteban, M., M. C. Garcia-Ara, M. Banque-Molas, M. T. Boyano-Martinez, F. Martin-Munoz, and J. M. Diaz-Pena. 1998. Evaluation of an extensively hydrolyzed casein-whey protein formula in immediate cow's milk protein hypersensitivity. J. Pediatr. Gastroenterol. Nutr. 26:398-401.

Maruyama, S., H. Mitachi, J. Awaya, M. Kurono, N. Tomizuka, and H. Suzuki. 1987. Angiotensin I-converting enzyme inhibitory activity of the C-terminal hexapeptide of $\alpha \mathrm{S}_{1}$-casein. Agric. Biol. Chem. $54: 2557-2561$.

Mattsby-Balzer, I., A. Roseanu, C. Motas, J. Elverfors, I. Engberg, and L. A. Hanson. 1996. Lactoferrin or a fragment thereof inhibits the endotoxin-induced interleukin-6 response in human monocytic cells. Pediatr. Res. 40:257-262.

McCann, K. B., A. Lee, J. Wan, H. Roginski, and M. J. Coventry. 2003. The effect of bovine lactoferrin and lactoferricin B on the ability of feline calicivirus (a norovirus surrogate) and poliovirus to infect cell cultures. J. Appl. Microbiol. 95:1026-1033.

Meisel, H. 1998. Overview on milk protein-derived peptides. Int. Dairy J. 8:363-373.

Meisel, H., and R. J. FitzGerald. 2003. Biofunctional peptides from milk proteins, mineral binding and cytomodulatory effects. Curr. Pharm. Des. 9:1289-1295.

Meisel, H., and E. Schlimme. 1996. Bioactive peptides derived from milk proteins: Ingredients for functional foods? Kieler Milchwirts. Forsch. 48:343-357.

Mercier, A., S. F. Gauthier, and I. Fliss. 2004. Immunomodulating effects of whey proteins and their enzymatic digests. Int. Dairy J. $14: 175-183$.

Mills, E. N. C., M. J. C. Alcocer, and M. R. A. Morgan. 1992. Biochemical interactions of food-derived peptides. Trends Food Sci. Technol. 3:64-68.

Minekus, M., P. Marteau, R. Havenaar, and J. H. J. Huis in't Veld. 1995. A multi compartmental dynamic computer-controlled model simulating the stomach and small intestine. ATLA 23:197-209.

Molly, K., M. van de Woestyne, and W. Verstraete. 1993. Development of a 5-step multi-chamber reactor as a simulation of the human 
intestinal microbial ecosystem. Appl. Microbiol. Biotechnol. $39: 254-258$.

Mullally, M. M., H. Meisel, and R. J. FitzGerald. 1996. Synthetic peptides corresponding to $\alpha$-LA and $\beta$-LG sequences with angiotensin-I-converting enzyme inhibitory activity. Biol. Chem. Hoppe Seyler 377:259-260.

Mullally, M. M., H. Meisel, and R. J. FitzGerald. 1997. AngiotensinI-converting enzyme inhibitory activities of gastric and pancreatic proteinase digests of whey proteins. Int. Dairy J. 7:299-303.

Murakami, M., H. Tonouchi, R. Takahashi, H. Kitazawa, Y. Kawai, H. Negishi, and T. Saito. 2004. Structural analysis of a new antihypertensive peptide ( $\beta$-lactosin B) isolated from a commercial whey product. J. Dairy Sci. 87:1967-1974.

Nagaoka, S., Y. Futumura, K. Miwa, T. Awano, K. Yamauchi, Y. Kanamaru, K. Tadashi, and T. Kuwata. 2001. Identification of novel hypocholesterolemic compound derived from bovine milk beta-lactoglobulin. Biochem. Biophys. Res. Commun. 281:1117.

Nakamura, Y., N. Yamamoto, K. Sakai, and T. Takano. 1995. Antihypertensive effect of sour milk and peptides isolated from it that are inhibitors to angiotensin I-converting enzyme. J. Dairy Sci. $78: 1253-1257$

Neeser, J.-R., A. Chambaz, S. del Vedovo, M.-J. Prigent, and B. Guggenheim. 1988. Specific and nonspecific inhibition of adhesion of oral actinomyces and streptococci to erythrocytes and polystyrene by caseinoglycopeptide derivatives. Infect. Immun. $56: 3201-3208$.

Nurminen, M.-L., M. Sipola, H. Kaarto, A. Pihlanto-Leppälä, K. Piilola, R. Korpela, O. Tossavainen, H. J. T. Korhonen, and H. Vapaatalo. 2000. $\alpha$-Lactorphin lowers blood pressure measured by radiotelemetry in normotensive and in spontaneously hypertensive rats. Life Sci. 66:1535-1543.

Ohinata, K., A. Inui, A. Asakawa, K. Wada, E. Wada, and M. Yoshikawa. 2002. Albutensin A and complement C3a decrease food intake in mice. Peptide 27:127-133.

Ondetti, M. A., and D. W. Cushman. 1982. Enzymes of the reninangiotensin system and their inhibitors. Annu. Rev. Biochem. 51:283-308.

Oomen, A. G., A. Hack, M. Minekus, E. Zeijdner, C. Cornelis, G. Schoeters, W. Verstraete, T. van de Wiele, J. Wragg, C. J. M. Rompelberg, A. Sips, and J. H. van Wijnen. 2002. Comparison of five in vitro digestion models to study the bioaccessibility of soil contaminants. Environ. Sci. Technol. 36:3326-3334.

Ortiz-Chao, P., J. A. Gomez-Ruiz, R. A. Rastall, D. Mills, R. Cramer, A. Pihlanto, H. Korhonen, and P. Jauregi. 2009. Production of novel ACE inhibitory peptides from $\beta$-lactoglobulin using Protease N Amano. Int. Dairy J. 19:69-76.

Pecquet, S., L. Bovetto, F. Maynard, and R. Fritsché. 2000. Peptides obtained by tryptic hydrolysis of bovine $\beta$-lactoglobulin induce specific oral tolerance in mice. J. Allergy Clin. Immunol. 105:514521.

Pellegrini, A., C. Dettling, U. Thomas, and P. Hunziker. 2000. Isolation and characterisation of four bactericidal domains in the bovine $\alpha$-lactoglobulin. Biochim. Biophys. Acta 1526:131-140.

Pellegrini, A., U. Thomas, N. Bramaz, P. Hunziker, and R. von Fellenberg. 1999. Isolation and identification of three bactericidal domains in the bovine $\alpha$-lactalbumin molecule. Biochim. Biophys. Acta 1426:439-448.

Perea, A., and U. Ugalde. 1996. Continuous hydrolysis of whey proteins in a membrane recycle reactor. Enzyme Microb. Technol. $18: 29-34$

Pietrantoni, A., M. G. Ammendolia, A. Tinari, R. Siciliano, P. Valenti, and F. Superti. 2006. Bovine lactoferrin peptidic fragments involved in inhibition of echovirus 6 in vitro infection. Antivir. Res. 69:98-106.

Pihlanto-Leppälä, A., P. Koskinen, K. Piilola, T. Tupasela, and H. Korhonen. 2000. Angiotensin I-converting enzyme inhibitory properties of whey protein digests: Concentration and characterization of active peptides. J. Dairy Res. 67:53-64.

Pihlanto-Leppälä, A., I. Paakkari, M. Rinta-Koski, and P. Antila 1997. Bioactive peptide derived from in vitro proteolysis of bovine $\beta$-lactoglobulin and its effect on smooth muscle. J. Dairy Res. 64:149-155.

Pihlanto-Leppälä, A., T. Rokka, and H. Korhonen. 1998. Angiotensin I-converting enzyme inhibitory peptides from bovine milk proteins. Int. Dairy J. 8:325-331.

Pins, J. J., and J. M. Keenan. 2006. Effects of whey peptides on cardiovascular disease risk factors. J. Clin. Hypertens. 8:775782 .

Potter, S. 1995. Overview of proposed mechanisms for the hypocholesterolemic effect of soy. J. Nutr. 125:606-611.

Prioult, G., S. Pecquet, and I. Fliss. 2004. Stimulation of interleukin-10 production by acidic beta-lactoglobulin-derived peptides hydrolyzed with Lactobacillus paracasei NCC2461 peptidases. Clin. Diagn. Lab. Immunol. 11:266-271.

Recio, I., and S. Visser. 1999. Two ion-exchange chromatographic methods for the isolation of antibacterial peptides from lactoferrin: In situ enzymatic hydrolysis on an ion-exchange membrane. J Chromatogr. 831:191-201.

Reid, I. R., J. Cornish, N. W. Haggarty, and K. P. Palmano. 2004. Bone health compositions derived from milk. US patent US2004052860. New Zealand Dairy Board, assignee.

Roufik, S., S. F. Gauthier, and L. T. Sylvie. 2007. Physicochemical characterization and in vitro digestibility of $\beta$-lactoglobulin $/ \beta-\mathrm{Lg}$ f142-148 complexes. Int. Dairy J. 7:471-480.

Roufik, S., S. F. Gauthier, and S. L. Turgeon. 2006. In vitro digestibility of bioactive peptides derived from bovine $\beta$-lactoglobulin. Int Dairy J. 16:294-302.

Saint-Sauveur, D., S. F. Gauthier, Y. Boutin, A. Montoni, and I. Fliss. 2009. Effect of feeding whey peptide fractions on the immune response in healthy and Escherichia coli infected mice. Int. Dairy J. 19:537-544.

Saito, T., T. Nakamura, H. Kitazawa, Y. Kawai, and T. Itoh. 2000. Isolation and structural analysis of antihypertensive peptides that exist naturally in Gouda cheese. J. Dairy Sci. 83:1434-1440.

Samuelsen, Ø., H. H. Haukland, H. Ulvatne, and L. H. Vorland. 2004. Anti-complement effects of lactoferrin-derived peptides. FEMS Immunol. Med. Microbiol. 41:141-148.

Schmidt, R. H., V. S. Packardm, and H. A. Morris. 1984. Effects of processing on whey protein functionality. J. Dairy Sci. 67:27232733.

Schupbach, P., J. R. Neeser, M. Golliard, M. Rouvet, and B. Guggenheim. 1996. Incorporation of caseinoglycomacropeptide and caseinophosphopeptide into the salivary pellicle inhibits adherence of mutant streptococci. J. Dent. Res. 75:1779-1788.

Scollard, P. G., T. P. Beresford, P. M. Murphy, and A. L. Kelly. 2000 Barostability of milk plasmin activity. Lait 80:609-619.

Shah, N. P. 2000. Effects of milk-derived bioactives: An overview. Br. J. Nutr. 84 (Suppl. 1):S3-S10.

Shimazaki, K., T. Tazume, K. Uji, M. Tanaka, H. Kumura, K. Mikawa, and T. Shimo-Oka. 1998. Properties of a heparin-binding peptide derived from bovine lactoferrin. J. Dairy Sci. 81:2841-2849.

Shin, K., K. Yamauchi, S. Teraguchi, H. Hayasawa, M. Tomita, Y. Otsuka, and S. Yamazaki. 1998. Antibacterial activity of bovine lactoferrin and its peptides against enterohaemorrhagic Escherichia coli O157 7. Lett. Appl. Microbiol. 26:407-411.

Siciliano, R., B. Rega, M. Marchetti, L. Seganti, G. Antonini, and P. Valenti. 1999. Bovine lactoferrin peptidic fragments involved in inhibition of herpes simplex virus type 1 infection. Biochem. Biophys. Res. Commun. 264:19-23.

Silva, S. V., and F. X. Malcata. 2004. Caseins as source of bioactive peptides. Int. Dairy J. 15:1-15.

Sipola, M., P. Finckenberg, R. Korpela, H. Vapaatalo, and M.-L. Nurminen. 2002. Effect of long-term intake of milk products on blood pressure in hypertensive rats. J. Dairy Res. 69:103-111.

Smacchi, E., and M. Gobbetti. 2000. Bioactive peptides in dairy products, synthesis and interaction with proteolytic enzymes. Food Microbiol. 17:129-141.

Smithers, G. W., J. B. Ballard, A. D. Copeland, J. A. Kirthi, D A. Dionysius, G. L. Francis, C. Goddard, P. A. Grieve, G. H Mcintosh, I. R. Mitchell, R. J. Pearce, and G. O. Regester. 1996 Symposium: Advances in dairy foods processing and engineering 
new opportunities from the isolation and utilization of whey proteins. J. Dairy Sci. 79:1454-1459.

Sorensen, E. S., and T. Petersen. 1993. Purification and characterization of three proteins from the proteose peptone fraction of bovine milk. J. Dairy Res. 60:189-197.

Sorensen, E. S., L. K. Rasmussen, L. Moller, and T. E. Petersen. 1997. The localization and multimeric nature of component PP3 in bovine milk: Purification and characterization of PP3 from caprine and ovine milks. J. Dairy Sci. 80:3176-3181.

Takahashi, M., S. M. Moriguchi, T. Suganuma, H. Shiota, A. Takenaka, Y. Tani, F. S. Ryuzo, and M. Yoshikawa. 1998. Albutensin A an ileum-contracting peptide derived from serum albumin acts through both receptors for complements C3a and C5a. Lett. Pept. Sci. 5:29-35.

Tani, F., A. Shiota, H. Chiba, and M. Yoshikawa. 1993. Serophin an opioid peptide derived from bovine serum albumin. Pages 49-53 in $\beta$-Casomorphins and Related Peptides: Recent Developments. V. Brantl, ed. VCH-Verlag, Weinheim, Germany.

Tomé, D., and N. Ledoux. 1998. Nutritional and physiological role of milk protein components. Dairy Foods in Health Bulletin of the International Dairy Federation. 336:11-16. International Dairy Federation, Brussels, Belgium.

Tomita, M., W. Bellamy, M. Takase, K. Yamauchi, H. Wakabayashi, and K. Kawase. 1992. Potent antibacterial peptides generated by pepsin digestion of bovine lactoferrin. J. Dairy Sci. 74:41374142.

Tyler-McMahon, B. M., M. Bolles, and E. Richelson. 2000. Neurotensin: Peptide for the next millennium. Regul. Pept. 93:125-126.

van der Kraan, M. I. A., J. Groenink, K. Nazmi, E. C. I. Veerman, J. G. J. Bolscher, and A. V. N. Amerongen. 2004. Lactoferrampin: A novel antimicrobial peptide in the N1-domain of bovine lactoferrin. Peptides 25:177-183.

van der Kraan, M. I. A., K. Nazmi, A. Teeken, J. Groenink, W. van't Hoff, and E. C. I. Veerman. 2005. Lactoferrampin an antimicrobial peptide of bovine lactoferrin exhibits its candidacidal activity by a cluster of positively charged residues at the C-terminus in combination with a helix facilitating N-terminal part. J. Biol. Chem. 386:137-142.

Vermeirssen, V., B. Deplacke, K. A. Tappenden, J. van Camp, H. R. Gaskins, and W. Verstraete. 2002. Intestinal transport of the lactokinin Ala-Leu-Pro-Met-His-Ile-Arg through a Caco-2 Bbe monolayer. J. Pept. Sci. 8:95-100.

Viejo-Díaz, M., M. T. Andrés, and J. F. Fierro. 2005. Different antiCandida activities of two lactoferrin-derived peptides Lfpep and kaliocin-1. Antimicrob. Agents Chemother. 49:2583-2588.

Vogel, H. J., D. J. Shibli, W. Jing, E. M. Lohmeiher-Vogel, R. F. Epand, and R. M. Epand. 2002. Towards a structure-function analysis of bovine lactoferricin and related tryptophan- and arginine-containing peptides. Biochem. Cell Biol. 80:49-63.
Vorland, L. H., H. Ulvatne, O. Rekdal, and J. S. Svendsen. 1999. Initial binding sites of antimicrobial peptides in Staphylococcus aureus and Escherichia coli. Scand. J. Infect. Dis. 31:467-473.

Wakabayashi, H., S. Abe, T. Okutomi, S. Tansho, K. Kawase, and H. Yamaguchi. 1996. Cooperative anti-Candida effects of lactoferrin or its peptides in combination with azole antifungal agents. Microbiol. Immunol. 40:821-825.

Wakabayashi, H., H. Matsumoto, K. Hashimoto, S. Teraguchi, M. Takase, and H. Hayasawa. 1999. N-Acylated and D-enantiomer derivatives of a nonamer core peptide of lactoferricin B showing improved antimicrobial activity. Antimicrob. Agents Chemother. 43:1267-1269.

Wakabayashi, H., M. Takase, and M. Tomita. 2003. Lactoferricin derived from milk protein lactoferrin. Curr. Pharm. Des. 9:12771287.

Walsh, D. J., H. Bernard, B. A. Murray, J. MacDonald, A.-K. Pentzien, G. A. Wright, J.-M. Wal, A. D. Struthers, H. Meisel, and R. J. FitzGerald. 2004. In vitro generation and stability of the lactokinin $\beta$-lactoglobulin fragment (142-148). J. Dairy Sci. 87:3845-3857.

Wong, K. F., N. Middleton, M. Montgomery, M. Dey, and R. I. Carr. 1998. Immunostimulation of murine spleen cells by materials associated with bovine milk protein fractions. J. Dairy Sci. $81: 1825-1832$.

Yamamoto, N., M. Maeno, and T. Takano. 1999. Purification and characterization of an antihypertensive peptide from a yogurt-like product fermented by Lactobacillus helveticus CPN4. J. Dairy Sci. 82:1388-1393.

Yamauchi, K. 1992. Biologically functional proteins of milk and peptides derived from milk proteins. Bull. Int. Dairy Fed. 272:51-58.

Yamauchi, K., M. Tomita, T. J. Giehl, and R. T. Ellison. 1993. Antibacterial activity of lactoferrin and a pepsin-derived lactoferrin peptide fragment. Infect. Immun. 61:719-728.

Yamauchi, R., K. Ohinata, and M. Yoshikawa. 2003a. $\beta$-Lactotensin and neurotensin rapidly reduce serum cholesterol via NT2 receptor. Peptides 24:1955-1961.

Yamauchi, R., H. Usui, J. Yunden, Y. Takenaka, F. Tani, and M. Yoshikawa. 2003b. Characterization of $\beta$-lactotensin a bioactive peptide derived from bovine $\beta$-lactoglobulin as a neurotensin agonist. Biosci. Biotechnol. Biochem. 67:940-943.

Yvon, M., S. Beucher, P. Guilloteau, I. le Huerou-Luron, and T. Corring. 1994. Effects of caseinomacropeptide (CMP) on digestion regulation. Reprod. Nutr. Dev. 34:527-537.

Yvon, M., S. Beucher, P. Scanff, S. Thirouin, and J. P. Pelissier. 1992. In vitro simulation of gastric digestion of milk proteins: Comparison between in vitro and in vivo data. J. Agric. Food Chem. 40:239-244.

Zhang, X., and A. C. Beynen. 1993. Influence of dietary fish proteins on plasma and liver cholesterol concentrations in rats. Br. J. Nutr. 69:767-777. 